\title{
Segunda serie programática de Pedro Rodríguez Miranda
}

\author{
M. ${ }^{\text {a }}$ Teresa Jimenez Priego *
}

Lo mejor de la pintura de Pedro Rodríguez de Miranda corresponde, sin duda, a sus dos series programáticas - la que historia la vida del Fundador del Carmelo y la que inmortaliza los origenes de la Institución de Clérigos Regulares Menores-.

Entre ellas existen marcadas diferencias. La referida a Elias, objeto de uno de nuestros últimos artículos ', une a su calidad artística el valor imponderable de ser un conjunto que permanece en el mismo entorno y distribución para el que fue creado. En cambio los lienzos referidos a la orden de Clérigos Menores se hallan dispersos —dos han vuelto al Museo del Prado y un tercero sigue custodiándose, desde hace casi un siglo, en tierras catalanas-.

En esta última serie podemos gozar de sus aciertos pictóricos y de la maestría de su dibujo y color, pero para siempre carecemos de las connotaciones que ofrecieran su primer ambiente y disposición.

Sin duda, Pedro Rodriguez de Miranda recibió el encargo de pintar estos lienzos y otras pinturas $u$ obras para esta misma Orden, de las que hablaremos, a través del P. Aller, Clérigo Menor estrechamente vinculado al Palacio Real, como confesor del Infante don Felipe, cuarto hijo de Felipe $V$, y al que acompañó en sus salidas oficiales ${ }^{2}$.

* Departamento de Historia del Arte. UNED.

1 "Un conjunto de pinturas de Pedro Rodríguez de Miranda", en Espacio, Tiempo y Forma. Serie VII, t. 2, 1989, págs. 133-168.

${ }^{2}$ Archivo del Palacio Real de Madrid. Expediente personal del P. Aller. 
De la génesis y desarrollo de estas pinturas tratamos a continuación.

La actividad y encuentros en Palacio debieron estrechar la amistad entre el pintor y el clérigo. El artista tuvo que realizar varios lienzos para el Infante: -una Inmaculada, paisajes, bambochadas, etc.-, en los que la influencia y recomendaciones del religioso estuvieron muy presentes, como anota Ceán ${ }^{3}$.

La satisfacción y el éxito con el que fueron acogidas estas obras sirvió para encomendarle la realización de la historia de la Orden de Clérigos Menores, a la que, como hemos dicho, pertenecía el citado P. Aller. Estos seriales pictóricos, habituales en la historia del Arte, eran auténticas crónicas de carácter histórico, muchas veces más puntuales incluso que las escritas.

No existen datos suficientes para saber con exactitud cuántos fueron los cuadros pintados por Pedro Rodríguez de Miranda, dado que sólo conservamos tres. Sin embargo, teniendo en cuanta los diversos inventarios consultados ${ }^{4}$, el número de estos lienzos pudo ser superior. El mismo Ceán y Ponz, como diremos, tampoco son unánimes.

${ }^{3}$ Diccionario histórico de los más ilustres profesores de las Bellas Artes en España. Madrid 1965 (1800) , IV, 222.

${ }^{4}$ Los inventarios consultados pueden dividirse en dos grandes grupos. Uno que corresponde a los inventarios realizados sobre las obras incautadas a los conventos que desaparecieron al aplicar los decretos de Napoleón y José 1 Bonaparte, el 12 de agosto y el 4 de diciembre de 1808, repectivamente. Decretos que respondían a su deseo de reducir los conventos a su tercera parte (agrupando en una sola casa los frailes de diferentes conventos de la misma orden) y convertir sus propiedades en bienes nacionales. La supresión de conventos y la elaboración de los inventarios de sus obras artisticas y bibliotecas se prolonga hasta fines de 1809, pues en un expediente del 5 de noviembre de ese año el Ministro de Hacienda solicita copia de los inventarios de las pinturas (APO Registro de Expedientes -Ministerio del Interior- 1809-1811, exp. 221). Esta tarea "de control" y custodia se continua hasta 1813 y 1814, por lo que, con razón, Madrazo, Mariano de, (Historia del Museo del Prado, 1818-1868. Madrid 1945, págs. 51-52) apunta que se hicieron copiosas anotaciones para saber los cuadros que contenía cada convento.

El otro grupo está integrado por los inventarios de las obras devueltas a los conventos madrileños tras la ocupación francesa.

Los inventarios de las pinturas de los conventos, o sea los que integran el primer grupo, está repartidos por varios archivos: en la Sección de Gracia y Justicia del A. de Simancas; en la Sección de Consejos del A. Histórico Nacional, en Madrid, y en el Archivo de Palacio, también en Madrid, en los "Papeles reservados de Fernando VIl".

Varios de estos inventarios son recogidos por CASTILLO, Antigüedad del, en el Apéndice de su Tesis Doctoral José Bonaparte y el Patrimonio Artistico de los conventos madrileños. Madrid, Universidad Complutense, 1987.

Los inventarios correspondientes al segundo grupo, se incluyen en un manuscrito perteneciente a una biblioteca particular madrileña. RINCÓN GARCía, Wifredo, publica estos documentos y hace el estudio de ellos en "Un manuscrito con inventarios artísticos de conventos madrileños en 1814" (Academia, núm. 60. Madrid 1985, págs. 300 a 372). Ver también las notas 10 y 14 . 
Antes de comenzar el análisis de las pinturas conocidas, conviene hacer una breve historia de la Orden, su fundación y difusión, ya que, lógicamente, el estudio de un programa iconográfico nunca puede desvincularse del momento histórico en el que se produce y de los mensajes que intenta transmitir en el mismo.

La Orden de Clérigos Regulares Menores nació en Nápoles y tuvo como especial dedicación la adoración del Santísimo Sacramento. Según el P. Eusebio Quintana ${ }^{5}$ esta orden fue creada para llenar el vacio producido al desaparecer los dos monasterios ingleses ${ }^{6}$ que tenian este mismo fin.

Sus fundadores fueron Juan Agustín Adorno, Francisco (Ascanio) Caracciolo y Agustín (Fabricio) Caracciolo, que contaron siempre con la estrecha colaboración y afecto del Papa Sixto $V^{\text {? }}$.

Juan Agustín Adorno (1551-1591) era un noble genovés, perteneciente a una de las familias más distinguidas en la República. A causa de las luchas que los nobles mantenían con la familia Adorno, por orden de su padre, so pretexto de graves negocios, pasa a la Corte de España. En su traslado hizo escala en Valencia. Cuando visitaba los claustros del Convento de Santo Domingo, de la Orden de Predicadores, San Luis Beltrán al verlo se postró de rodillas. Extrañado Adorno le preguntó la causa de aquella acción o actitud. El Santo le respondió "que lo veneraba asi porque habia de ser Fundador de una Religión que daría mucho fruto a la Iglesia de Dios" ${ }^{8}$.

Vuelto Juan Agustín a Génova y transcurrido un cierto tiempo, siente el deseo de ser religioso. Al pensar en qué Orden debia consagrarse, recordó ia profecía de San Luis. Confirmado por su confesor, se anima a ponerla en práctica. Marcha al desierto de Val-Umbrosa, cerca de Florencia, donde, en oración y penitencia, redacta unas reglas.

En Nápoles, en 1587, es ordenado sacerdote. Ingresó en la Congregación de los Blancos o de María Santísima, donde trató a don Fabricio

${ }^{5}$ Prodigiosa vida del muy ilustre varón, y extático héroe, comunmente conocido por el $P$. de la caridad, y por el predicador del amor de Dios el B. P. Francisco Caracciolo, fundador de la Sagrada Religión de los Clérigos Menores. Madrid 1769, 2a. y 3a. p. del "Proemio". (BNM: 2/7917 = B. MO. Escorial: 93-IX-1).

" "Llamados el Dúplice de Sión... y el Belén de monjes cartujanos", en las riberas del Támesis.

7 Esta unión entre los cuatro miembros queda reflejada en el grabado de L. Spirinx, que sirve de portada al libro sobre el Comentario del Evangelio de San Mateo (Lugduni 1641), APONTE, P. Lorenzo, napolitano, Clérigo Regular Menor.

"Quintana, o.c., p. 28 y ss. 2a. p. de la "Introducción-Dedicatoria". 
Caracciolo, hombre ilustre, abad de Santa María la Mayor de Nápoles, iglesia y recinto que más tarde sería la primera casa de la Congregación (fig. 1).

Adorno contó a Fabricio su intento de crear un nuevo instituto Clerical y le invitó a colaborar con él. Tras dar forma a sus ideas escribe una nota («billete») a Frabicio para notificarle algunos "extremos". Se la envía a través de un mensajero, el cual, por equivocación, a causa del apellido, la entrega a Francisco. Este al leerlo advierte el error y lo remite a su destinatario. Francisco, sin embargo, interpreta este hecho como un signo de la Providencia y, tras un tiempo de reflexión, decide contactar con Juan Agustín poniéndose a su disposición para colaborar en la fundación.

Los tres unidos se retiran para redactar las Constituciones y el reglamento definitivos. Al volver a Nápoles se les unen otros muchos clérigos. Tras esto creen llegado el momento de solicitar la aprobación del Papa.

Adorno y Francisco Caracciolo son designados para ir a Roma. Tras la presentación de las Reglas al Papa Sixto $V$, el 1 de julio de 1588 reciben su Aprobación ${ }^{9}$. A partir de este momento queda constituida la Congregación.

Los protagonistas de estos hechos son también los protagonistas de los otros dos lienzos de Pedro Rodriguez de Miranda. A la vista del cuadro, contemplando la linajuda audiencia y acompañamiento, queda corroborada la ilustre procedencia familiar de los fundadores.

Nueve meses después de la Aprobación Pontificia de la Orden tiene lugar, el 9 de abril de 1589, el acto de la Profesión Solemne ante el Vicario General de la diócesis arzobispal de Nápoles, el M. I. Sr. D. Flamimio Torchela $-\mathrm{y}$ así nos lo subraya también la cartela inscrita en el tercer lienzo de los que estudiamos de Pedro Rodríguez de Miranda-. Esta función tuvo como escenario el Oratorio de Santa María de Sucurre Miseris, o de los Blancos, en Nápoles.

En este momento ya tienen perfilados su género de vida (ayuda a los enfermos y encarcelados), sus virtudes características (oración, penitencia y adoración ante el Santísimo), sus Patronos (la Inmaculada, San Miguel Arcángel, San José), su escudo de armas: la resurrección de Cristo, buscando sólo LA MAYOR GLORIA DE CRISTO RESUCITADO

"MARsot, "Clercs réguliers Mineurs". Catholicisme hier, aujourd hui, demain. T. II, Paris 1950, pág. 1215.-Chalumeau, R., "François Caracciolo (Saint)", en Catholicisme hier,.. T. IV. París 1956, pág. 1537.-Quintana, o.c., págs. 44 y ss. 


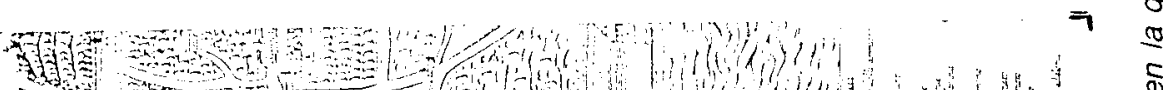

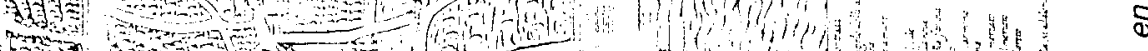

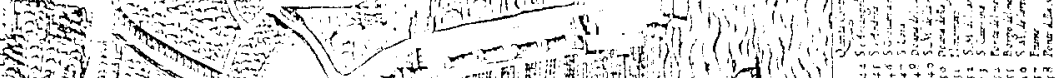

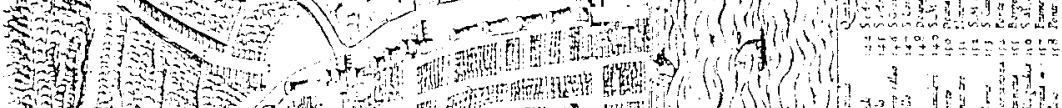

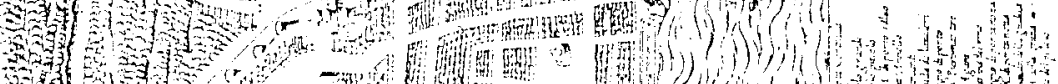

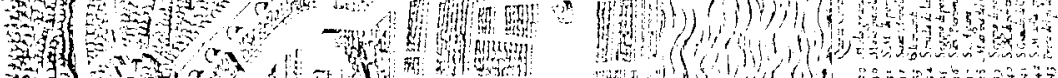

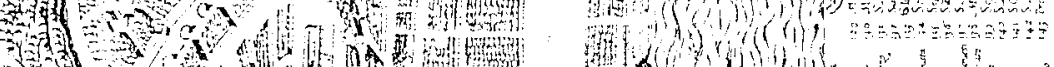

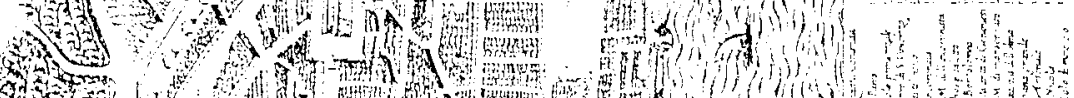
3.

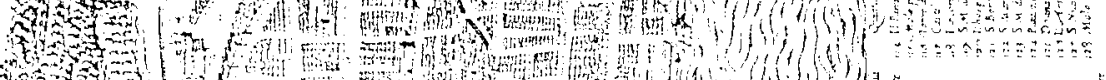
कof

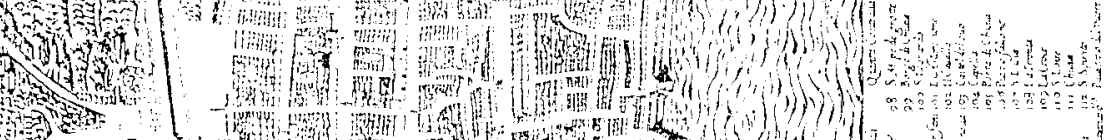

3.

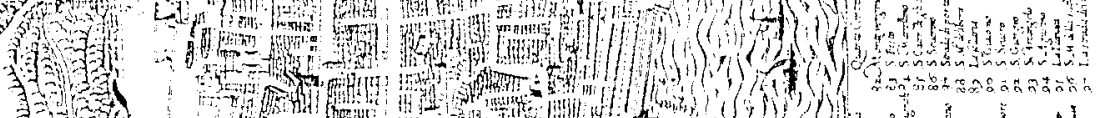

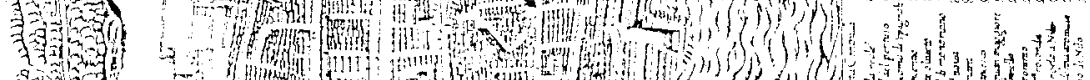

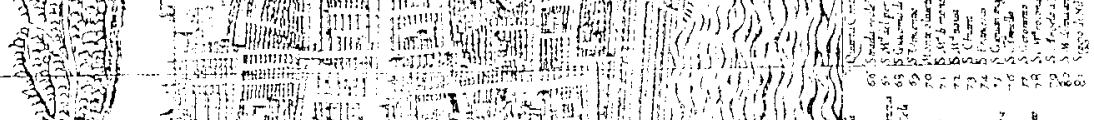

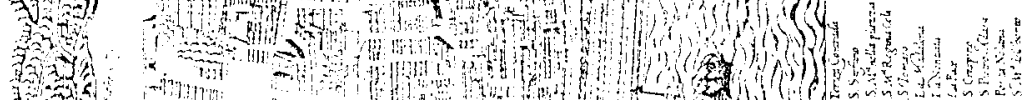

737 2

-

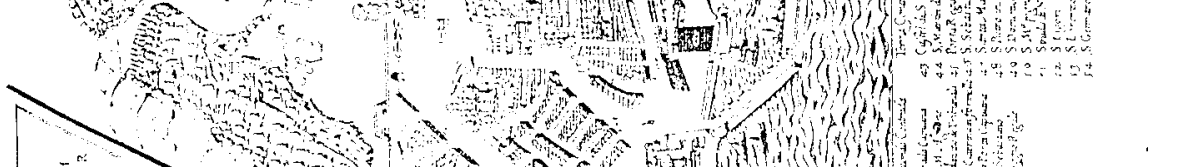

\&

$\stackrel{9}{0}$

क

$\stackrel{5}{2}$

T)

(⿻)

$\sum$

$\stackrel{0}{\mathscr{N}}$

8

$\frac{\pi}{5}$

פ

Q

8

จิ

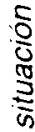

I

ฐ

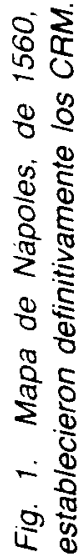


“AD MAYOREM RESURGENTIS GLORIAM» (figs. 2 a 4). ¡Nótese la trasposición terminológica del lenguaje nobiliario - escudo de armas- a una simbología de contenido religioso!.

En el comentario de los lienzos, que vamos a pasar a realizar, observaremos hasta qué extremo el artista recoge con fidelidad cada uno de estos datos.

Resta, únicamente, hacer mención de otros acontecimientos relevantes por ser de capital importancia en el estudio del artista que nos ocupa. Estos hechos se refieren a la expansión de la Congregación hacia España, con la creación de dos conventos en Madrid ${ }^{10}$ (Porta Coeli y del Espíritu Santo), uno en Alcalá de Henares (San José) ${ }^{11}$ y otro en Valla-

10 El documento de 1809 , que explicita la realización de lo decretado por Napoleón en julio de 1808, habla de estos dos conventos: "De los Clérigos Menores dos: el de Portacoeli, calle de la Luna, y el Espíritu Santo, carrera de San Geronimo; la yglesia de este convento se está arruinando, y asi podrán reunirse ambos en el de Portacelin. Archivo de Simancas. Gracia y Justicia. Leg. 1247.-Ponz, Viaje, V, 294-295, núm. 15, y 225, núm. 27.-AntigüEDAD, o.c., págs. 136-137: El convento del Espíritu Santo se fundó en 1594 en la Carrera de San Jerónimo (manzana 269). Al término de la guerra de la Independencia estaba muy destrozado, fue restaurado, pero un incendio de 1823 lo destruyó del todo, por lo que la comunidad pasó a Portacoeli. El templo de este convento fue la sede para la reunión de las Cortes en el año 1834 (BONET CORREA, Antonio, Iglesias madrileñas del siglo XVII. Madrid, CSIC, 1961 y 1984, pág. 56). Los grabados conservados nos lo presentan con una fachada austera rematada en frontón con óculo central y flanqueada por torres de agudo chapitel, la cúpula del crucero es poligonal con un cuerpo de ventanas y rematada por una cubierta bulbosa, era pues, una obra al estilo de principios del siglo xVII. ... En la sacristía tres grandes cuadros sobre la vida de la Beato Caracciolo pintados por Pedro Rodríguez de Miranda,... Todas las obras mencionadas aparecen recogidas en el inventario redactado en virtud de la enajenación de 1809 (Lista de los efectos pertenecientes al convento del Espíritu Santo. Archivo Simancas. Gracia y Justicia. Leg. 1247). En otras relaciones se habla de que el convento contaba con ciento veintidos cuadros, entre los que destacan los de Miranda y doce de Jordán, pero que Ponz no identifica (A.H.N. Madrid. Consejos. Leg. 17787).

El solar del Espíritu Santo fue ocupado por el edificio de las Cortes, después del derribo de los restos del convento y del templo en 1841.

El convento e iglesia de Clérigos Menores de Portacoeli ocupaba un solar de la manzana 368 de la calle de la Luna y se fundó en 1648. La iglesia parece que estaba ya construida en 1725 y en nuestros días perdura como parroquia de San Martín con una portada atribuida a Churriguera en la que, sobre la puerta, un grupo escultórico representa al fundador de los Clérigos, el venerabie Juan Agustín Adorno, ante la Virgen de Portacoeli.

El inventario redactado con motivo de la enajenación cita, sin embargo, gran cantidad de cuadros (A. Simancas. Gracia y Justicia. Leg. 1247) pero sin especificar los autores, entre los que destacan representaciones de San Felipe Neri, del Beato Caracciolo y de la Virgen de Portacoeli.-MORERI, Diccionario histórico. Paris 1753, T. III, pág. 203.

1 En 1601 o 1604, como casa de estudios.-Tormo (En Alcalá de Henares. s.a., págs. 19 y 46), habla del Colegio de los Caracciolos (los que en Madrid tenian casas en el hoy Congreso de los Diputados y en Portacoeli, hoy San Martín) fundado en 1604, conservado, y que hoy es parque de intervención y provisiones militares, todavía con estatua de San Francisco Caracciolo, y con muy grandiosa iglesia barroca. 


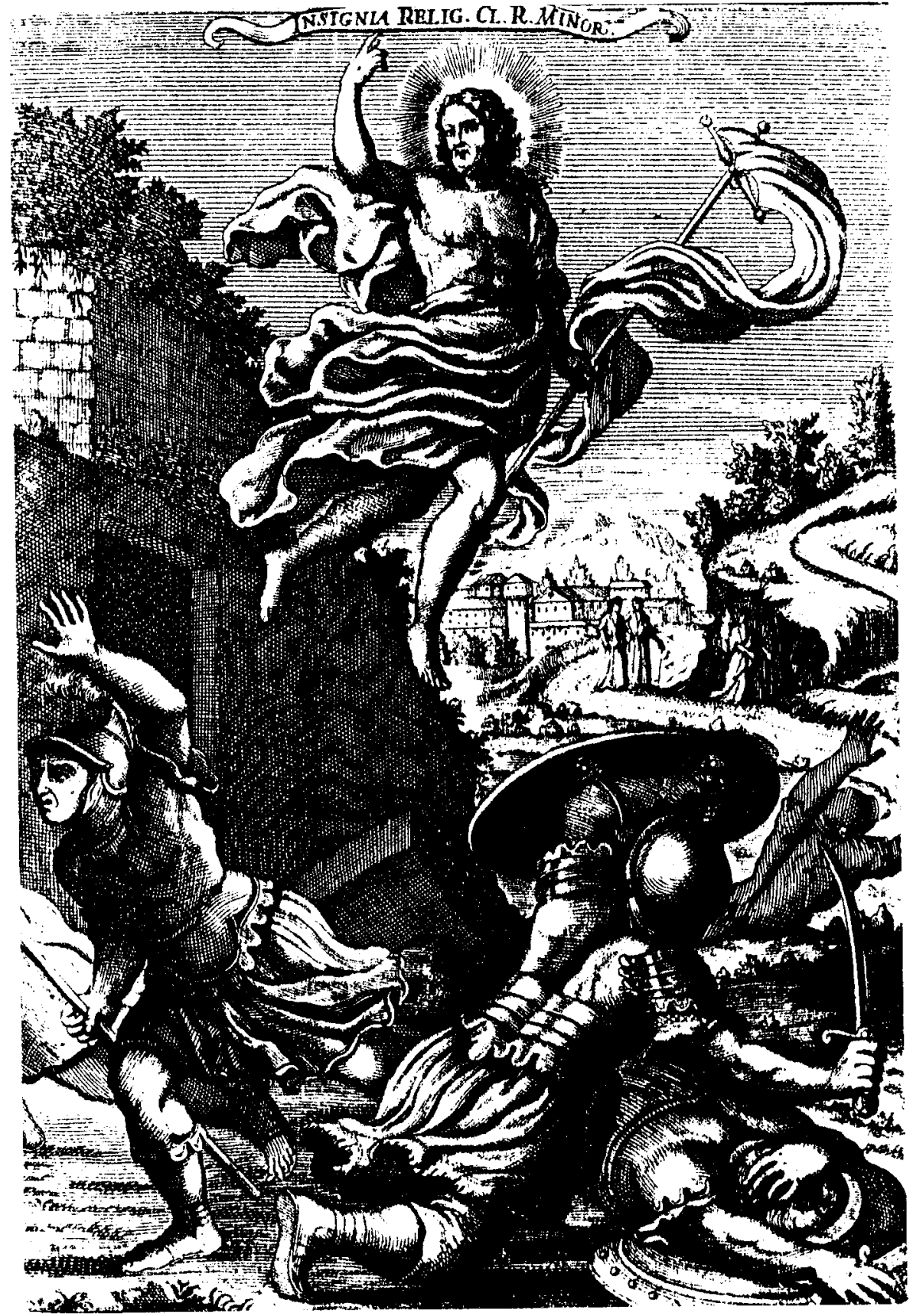

Fig. 2. Grabado de F. de Grado (1722). Representa la resurrección de Cristo como escudo e insignia de la Orden de CRM. 


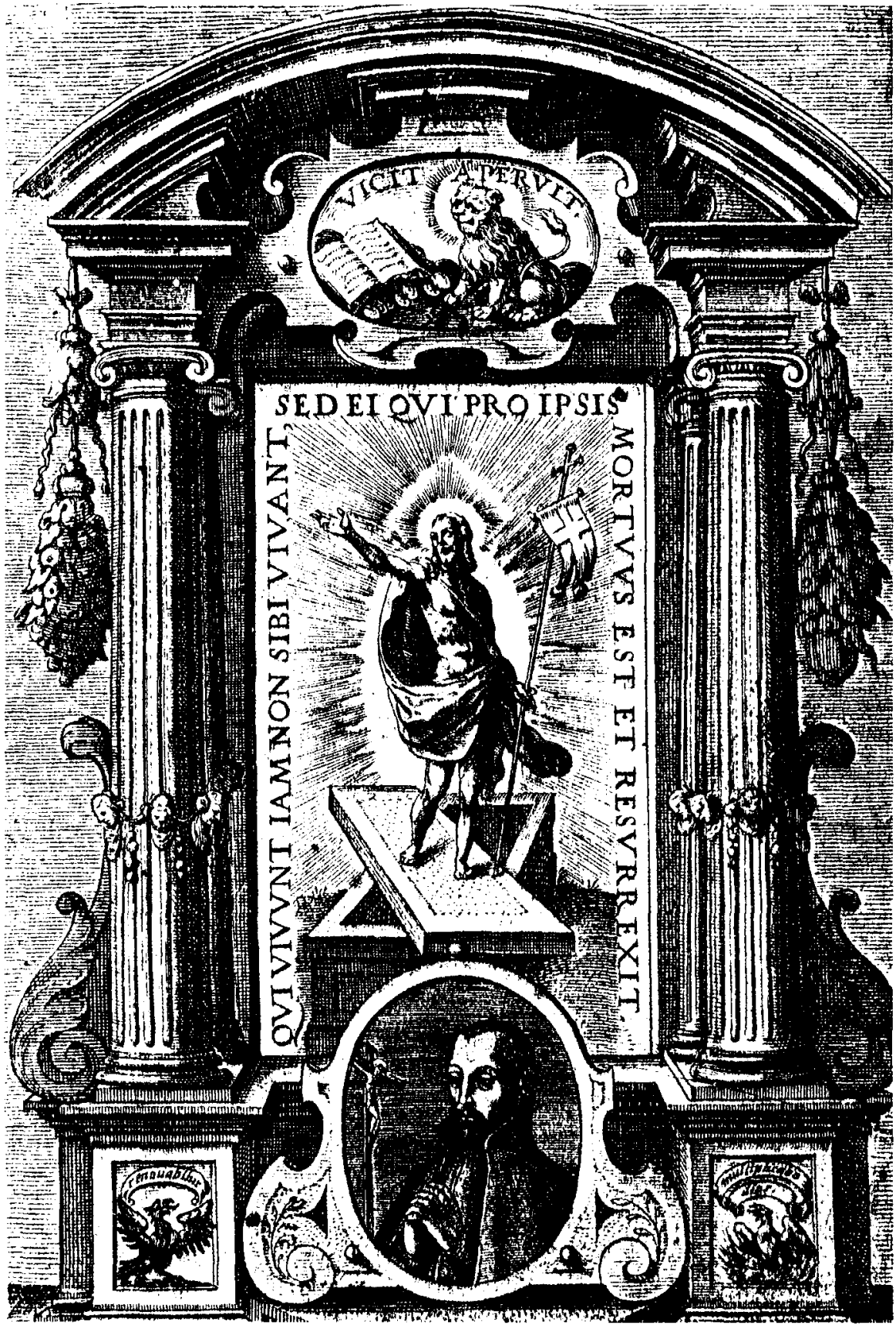

Fig. 3. Grabado de fines del siglo xvi. La insignia de la resurrección acompaña al fundador Juan Agustín Adorno. 


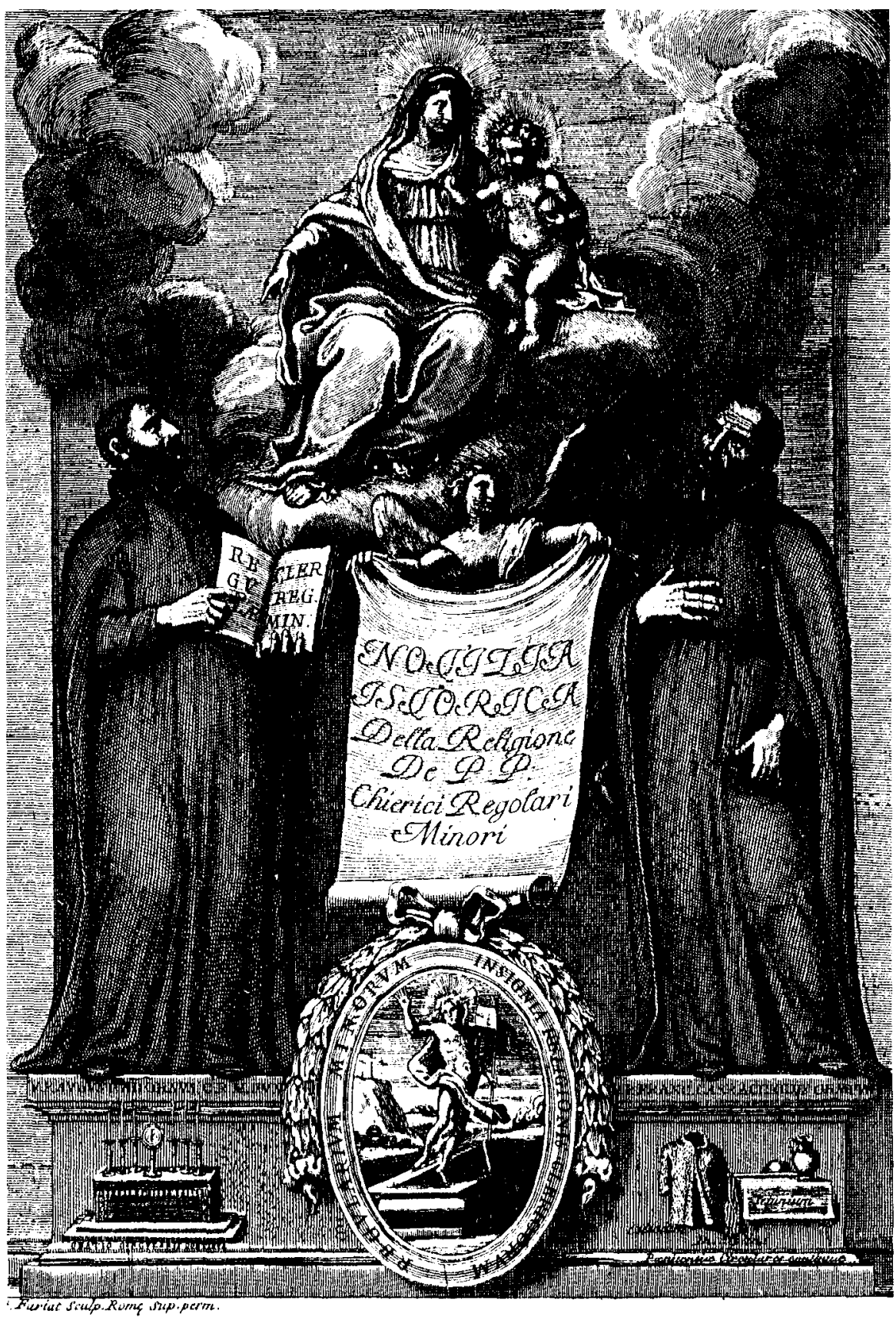

Fig. 4. Grabado de B. Fariat. Sintetiza el espiritu de la congregacion, sus devociones (la Virgen y el Niño), la insignia propia y los fundadores. 
dolid (Anunciación) ${ }^{12}$. Esta implatanción en España no fue empresa fácil dadas las dificultades presentadas por Felipe II, mitigidas, en parte, por el apoyo de todo tipo, hasta económico, que les prestó el ilustre personaje conocido por el nombre de Caballero de Gracia ${ }^{13}$.

Recordemos que tras la muerte de Adorno, acaecida el 29 de septiembre de 1591, coincidiendo con la festividad de su Patrono San Miguel, Francisco Caracciolo es nombrado General de la Orden, asume la responsabilidad y continua la tarea fundacional en España. Objetivo logrado, al fin, en 1599 y 1601 con la creación de los conventos anteriormente citados.

Si bien en los conventos madrileño existieron diversas pinturas relativas a la vida de Francisco Caraciolo y de Adorno, parece ser que es en el del Espíritu Santo donde se ubicaron estos tres lienzos que estudiamos.

Los diferentes inventarios ${ }^{14}$, realizados en 1809 y sus copias de 1813 y 1814 aluden a estos lienzos y aun citan su autor, de forma paralela a como lo hacen Ceán y Ponz.

12 Sobre estas fundaciones puede verse: "Clercs Réguliers Mineurs", Dictionnaire historique portatif des Ordres religeux et militaire et des congregations regulieres. Amsterdam 1769, pág. 209.-Croisset, P. Juan, Año Cristiano. T. 2. Madrid 1852, págs. 452-454, con un grabado.-Vie des Saints et des bienheureux selon l'ordre du Calendrier avec l'historique des fêtes. RR.PP. Bénedictines de Paris. T. IV, juin. París 1948 págs. 76-77.-Ponz, XI, IV., 117, 15.-New Catholic encyclopedia. N. York 1966.

13 Roscales Olea, Graciliano, El Caballero de Gracia. Más de cien años de aventura. Madrid, Avapiés, 1989 , págs. 140 a 151 principalmente. En el primer testamento el Caballero de Gracia manifiesta la convicción que tiene sobre "el futuro de los Clérigos Menores en los reinos de España; está convencido de que es la institución con mayor posibilidad expansiva". En 1594 tiene lugar la fundación, en su misma casa, de los Clérigos Regulares Menores. A esta casa y a la iglesia dieron la advocación de San José.-QuintanA, o.c., págs. 121-123 y 139-140.-ToRmo, E., en Las iglesias del antiguo Madrid. (Instituto de España, 1972 (1927), pág. 148, núm. 30), escribe: ... “Jacopo Grattiis (el llamado Caballero de Gracia)... contribuyó con celo y muchas riquezas a la fundación... y más al establecimiento en Madrid de los Clérigos Menores, a los que aposentó pocos años en el lugar (esquina Este de Clavel y esta calle (Caballero de Gracia), que al discrepar definitivamente con San Francisco Caracciolo, dio el Caballero de Gracia a las reformadas concepcionistas...".-MoreRI, O.C., T. III, pág. 203.-PISELLI, San Francesco Caracciolo. Napoli 1705, págs. 58 a 65 .

${ }^{14}$ Los Inventarios de las pinturas de los conventos están repartidos entre el Archivo de Simancas, Sección de Gracia y Justicia (leg. 1247); el Archivo Histórico Nal., Sección de Consejos (leg. 17787), y las copias literales que se hacen sobre el inventario original de las pinturas custodiadas en el depósito del Rosario, en el momento en que son trasladadas a la Real Academia de San Fernando; y en el Archivo de Palacio, en Madrid, entre los Papeles reservados a Fernando VII. Antiguedad del CAstillo, $o . c$.

En el leg. 1247 del A. Simancas (sección Gracia y Justicia) se hallan los inventarios "de los efectos pertenecientes a Ciencias y Artes hallados en el convento de PP. Clérigos Menores del Espíritu Santo de esta Corte" e idem del de Portacoeli, en el día de la supre- 
Estas pinturas, pues, fueron realizadas a petición de los religiosos del convento, entre los que debió encontrarse el P. Aller, dado que en el claustro de este Convento se custodiaba también un retrato suyo realizado asímismo por Pedro Rodríguez de Miranda. Este dato está corroborado por Ceán ${ }^{15}$ que afirma: "Retrató también al citado P. Aller de medio cuerpo, que está colocado en el claustro de los PP. del Espíritu Santo de Madrid, en cuya sacristía hay dos cuadros de su mano, relativos a la vida del beato Caracciolo" ${ }^{16}$. Y Ponz ${ }^{17}$ escribe al hablar del convento del Espíritu Santo de Clérigos Menores: "En la sacristía, los tres quadros grandes sobre los caxones, pertenecientes a la Vida del Beato Caracciolo, son de Pedro Rodríguez de Miranda" ${ }^{18}$.

Una vez orientado el lector con los datos mínimos y esenciales de la historia de la Congregación, pasamos a realizar el estudio iconográfico -iconológico, artístico y estético de este conjunto programático perteneciente a este artista madrileño del siglo XVIII-. Antes de abordar esta tarea hemos creido necesario realizar una investigaciion seria tanto sobre las fuentes literarias como sobre las gráficas que lo fundamentan. Fruto de esta investigación son las próximas páginas.

Siguiendo las indicaciones de Panofsky, Guy de Tervarent y González de Zárate ${ }^{19}$, entre otros, analizamos las fuentes literarias con objeto de acceder de forma acreditada a la interpretación de la significación intrínseca o contenido, en este caso imprescindibles, pues el simbolismo de ciertos elementos de la composición, así como la comprensión de algunas escenas, representadas simultáneamente y como de forma secundaria en relación con el tema principal, nos resultaban desconocidas.

Con sorpresa encontramos $-\mathrm{y}$ esto, a su vez, era otro dato revelador- que los santorales ${ }^{20}$ se ocupaban poco de los protagonistas de

sión... en Decreto de 18 de agosto de 1809. En la sacristía del convento del Espíritu Santo se citan "tres grandes quadros colocados sobre la caxonería pertenecientes a la vida del Bto. Caracciolo, obra de Don Pedro Rodriguez de Miranda.

15 O. C., IV, 222.

${ }^{16}$ Habla Ceán del beato Caracciolo pues su Diccionario se publica en 1800 y Francisco es Canonizado en 1807.

17 V. 295 , núm. 15.

18 El Viaje es de 1793, por ello da al futuro santo el tratamiento de beato.

19 Estudios de Iconologia. Madrid, Alianza, 1972, pág. 23; De la méthode iconologique. Bruselas 1961, y Método iconográfico. Vitoria-Gasteiz. Ephialte, 1991, respectivamente.

${ }^{20}$ Rybadeneyra, R. P. Pedro de (de la Comparíia de Jesús), Flos Sanctorum. Madrid 1716, no habla de Francisco Caracciolo, hecho explicable purque en esa fecha no era ni santo ni beato, pero ni siquiera lo cita en relación con el Papa Sixto V ( 3 . $^{\text {a }}$ parte, págs. 5388) que aprobó la Orden en 1588; asi como también omite el encuentro de Adorno, en Valencia, con San Luis Beltrán ( $5 .{ }^{\circ}$ parte, págs. $\left.387-412\right)$ tema de uno de los lienzos que recogemos. 
estos lienzos. Recogian, con mayor o menor amplitud, la vida y hechos de San Francisco Caracciolo, mas no de Juan Agustín Adorno, cofundador con el primero de la Orden de Clérigos Regulares Menores. Las aportaciones de Croisset ${ }^{21}$ o Villarrasa ${ }^{22}$ no pasan de vagas pinceladas que aportan poco para un esclarecimiento serio de datos e imágenes.

Como, aparentemente, no existía - pues no lo hallábamos - un texto escrito que nos permitiera reconstruir las líneas maestras del pensamiento y los hechos traducidos en imágenes, intentamos buscar ciclos pictóricos iguales o semejantes que nos sirvieran como elementos de comparación ${ }^{23}$. Analizamos 0 anotamos los rasgos comunes en todos ellos. Mas seguian persistiendo los mismos interrogantes sobre la identificación de símbolos u otros elementos.

Rastreamos las ideas básicas que informaron la mente del P. Aller, el clérigo inspirador de las obras. Sus fuentes, tratándose de un Clérigo Menor, debían estar muy claras, su biblioteca podia conocerse. Al fin, conseguimos la ya citada biografía, extensa y detallada, de San Francisco Caracciolo, escrita por el P. Eusebio Quintana, perteneciente a esta misma Orden, biografía que sin duda estuvo en las manos del P. Aller y de la cual incluso se le puede considerar promotor.

Esta obra, creemos, es la clave para la plena comprensión y acabado entendimiento de los detalles que "ilustran" los lienzos y grabados, asi como para conocer las fuentes de inspiración que manejó el artista en 1738 -fecha de su composición-. En efecto, por fortuna para nosotros, el P. Quintana recopila, analiza y contrasta lo narrado por los historiadores que le precedieron, subrayando sus aciertos y limitaciones.

Los escritos de estos biógrafos y cronistas "corrían" por los conventos de Clérigos Menores para alimento de los frailes ${ }^{24}, y$, como en este caso, servian también de base para que el artista o bien directamente o bien asesorado por uno de estos clérigos, reprodujera estas escenas en lienzos y colores.

21 Croisset, P. Juan, o. c., t. 2, págs. $452-454$.

22 Villarrasa, Eduardo María, La leyenda de Oro para cada día del año. Barcelona 1892, 4 de junio, págs. 388-393.

${ }^{3}$ Los de Vicente Carducho, los de Zurbarán, Sánchez Cotán, Le Sueur o Jouvenet sobre los Cartujos; los del P. Pozzo, Baciccia, Rubens, Roelas, Juan de Mesa,... Maratta, Pedro Valpuesta, Subleyras, sobre los Jesuitas; la representación de los Mercedarios por Zurbarán y Murillo, principalmente. Las series de Zurbarán, Murillo, Carducho o Ribalta sobre los franciscanos, etc., por no citar sino algunos.

${ }^{24}$ Para "enseñanza" de legos - siguiendo el carácter didáctico que el arte ha tenido siempre para la iglesia- y para enfervorizar a los letrados. 
El P. Quintana habla de la prioridad en el tiempo de la vida escrita por el académico napolitano don Ignacio Vives ${ }^{25}$, impresa en 1684; de la dedicación que el P. Clemente Piselli ${ }^{26}$, Cronista General de la Orden, le consagra en sus obras tan puntuaies como compendiosas. Llama la atención sobre la gran difusión que alcanzaron las páginas que dedica al santo Caracciolo, en español, el P. Villafranca ${ }^{27}$, catedrático de la Universidad de Salamanca, en la Crónica Sacra de los Clérigos Regulares Menores.

Mayor relevancia aún tuvo la Biografía del $P$. Domingo Fiumara ${ }^{28}$, al ser elegida por la Sagrada Congregación de Ritos para norma de los Procesos de Beatificación del Fundador, impresa en Roma en 1738.

En el apartado que titula «Prevenciones al lector», al inicio de su libro, el docto $P$. Quintana enaltece su obra sobre las anteriores, dado que al ser editada el año 1769, en que se beatifica a Francisco Caracciolo, dispone de un preciso y más amplio caudal de información al concluirse los Procesos de esta Causa, amén de otro Compendio del P. Cencelli ${ }^{29}$, impreso en Roma en ese mismo año y que consultó antes de terminar el suyo ${ }^{30}$.

La búsqueda de las fuentes gráficas de la obra de Pedro Rodríguez de Miranda fue paralela y similar a la efectuada en relación con las fuentes escritas, no así los resultados obtenidos. Sólo hallamos tres grabados, y de éstos, solamente uno podía ser la base o fuente de inspiración de las composiciones de Rodríguez Miranda. Se trata del grabado de L. Spirinx (fig. 5) ${ }^{31}$, de 1641 . Los otros dos, de Moreno Tejada ${ }^{32}$ y de Juan Antonio Salvador Carmona ${ }^{33}$ fueron realizados en 1769 el primero,

${ }^{25}$ Della vita del venerable servo di Dio P.F.C. Napoli 1864.

${ }^{26}$ Compendio della vita del veneralble servo di Dio P.F. Caracciolo. Napoli 1705. Notizie istoriche della religione de PP. Chierici Minori. Roma, 1710, fols. 82 al 104.

${ }^{27}$ Villafranca, P. Diego de, Crónica sacra de los Clérigos Regulares Menores. Madrid 1706, fols. 254 a 450 .

${ }_{28}$ Vida de San Francisco Caracciolo. Roma 1738, fols. 10-39.

${ }^{29}$ CENECELLI, P. Agustin, Compendio storico della vita e miracoli del beato Francesco Caracciolo. Rome 1769 y 1805.

${ }^{30}$ Gracias a la precisión con que el $P$. Quintana realiza sus citas podemos completar esta bibliografia con la dada en la nota 8 del "Proemio", la cual no la queremos omitir porque puede ser una posible fuente: MORERI, Luis, O.C. T. I, 146; T. II, 151 y 203; T. III, 203.

${ }^{31}$ Ver nota 7.

${ }^{32}$ Sirve de pórtico al citado libro del P. Eusebio Quintana. Lo comentamos en el estudio del cuadro de la Profesión.

33 BEDAT, en La Real Academia de Bellas Artes de San Fernando, 1744-1808. Madrid 1989 (1972), en la pág. 330, hablando de las láminas afirma que en el inventario hecho en 1804 se citan 154, que "estaban colgadas de las paredes de la Academia". Habla de todas 


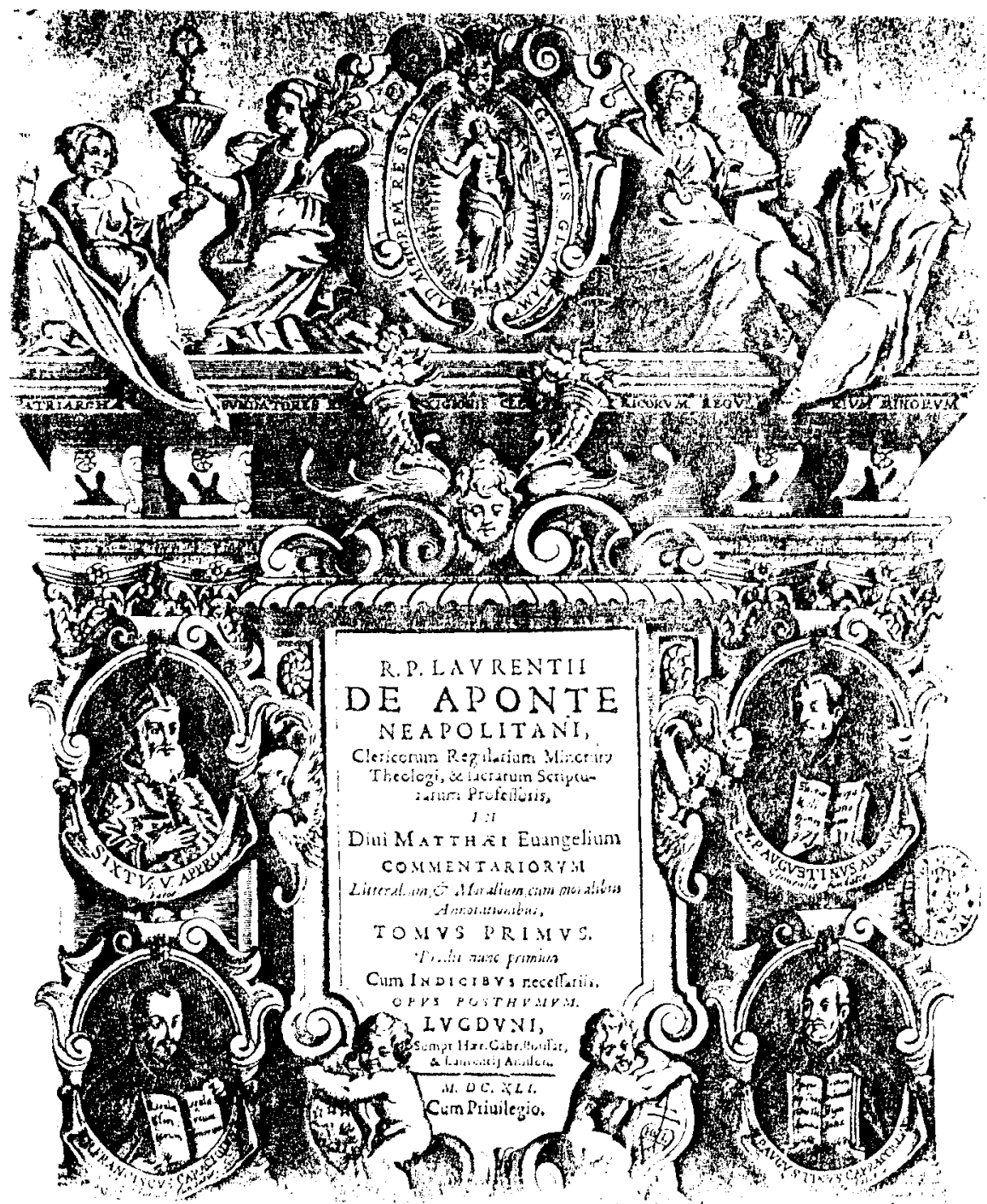

Fig. 5 Grabado de L. Spirinx, 164. Representa a los Fundadores y al Papa Sixto $\checkmark$ en sendos medallones. Sobre ellos, como en un frontón, cuatro alegorias portan los simbolos propios de la Congregación, completados, en la parte central, con la insignia de la resurrección. 
y el segundo de fecha próxima, quizás, también, con motivo de la celebración de la Beatificación del fundador (figs. 6 y 7).

Por Rodríguez-Moñino ${ }^{34}$ sabemos que el grabado de Juan Antonio Salvador Carmona fue encargado por los Clérigos menores del Espíritu Santo, y que él lo realizó "por dibujos de Ramón Bayeu»-dice textualmente- y de un tamaño superior al pliego. Aunque el grabado coincide en sus atributos y simbología con la de alguna de las obras pictóricas que estudiamos, ignoramos cuál seria el destino o finalidad de la obra. Se puede pensar sirvió de pórtico a alguna de las crónicas, historias de la orden o biografías del fundador, y con grandes probabilidades de ser ideado por el P. Aller, tan relacionado con esta iconografia.

Elena Páez en el Repertorio de grabados españoles de la Biblioteca Nacional ${ }^{35}$ habla de los de Juan Salvador Carmona, que cita Rodríguez Moñino en su Catálogo y de los que no existe prueba en la Biblioteca Nacional. Recoge éste del Beato Caracciolo, con el núm. 139, y repite el texto explicativo del citado investigador.

Menos significativo, desde el punto de vista iconográfico, aunque mucho más temprano, es el dibujo de José de Churriguera, firmado en Madrid, en 1719 (fig. 8). Diseña, con su estilo característico, el Retablo de San Francisco Caracciolo ${ }^{36}$, situando en el cuerpo central, sobre el ostensorio, un gran lienzo representando el Tránsito del Santo, y en la parte izquierda unos medallones con diferentes escenas alusivas a su vida.

Sin duda, este dibujo se correspondería con alguno de los retablos citados en los inventarios ya mencionados, retablos no conservados; los

ellas y textualmente escribe: "Habia también obras de sus mejores discipulos" (se refiere a Manuel Salvador Carmona): ... «y, por fin, una lámina de su hermano Juan Antonio Salvador Carmona que representaba al beato Francisco Caracciolo". En la actualidad no está en la Academia ni en la Calcografía Nacional. En cambio, si existe en los fondos del Museo Municipal de Madrid (núm. 18 del Catálogo del Gabinete de Estampas del Museo Municipal de Madrid. I. Estampas españolas Grabado 1550-1820. Vol. II. Elaborado por CARRETE, Juan, y otros. Ayuntamiento de Madrid, 1985), y en EPHiALTE, Instituto de Estudios Iconográficos, en Vitoria, al que agradecemos el envío de fax y fotografía.

34 Rodriguez-MoNino, A. y LoRD, Eileen A., Juan Antonio Salvador Carmona. Grabador del siglo XVIII (1740-1805). Noticias biográficas y Catálogo de sus obras. Madrid 1954, págs. 24 y 41 , núm. 139 del catálogo.

${ }_{35}$ Madrid 1983, págs. 89-90.

${ }^{36}$ BEDAT, Claude, o. c., pág. 396, lám. 76 y Academia. Bol. de la Real Academia de Bellas Artes de San Fernando. 1989, núm. 69, pág. 313 (277-373) «Inventarios de dibujos de la Real Academia de Bellas Artes de San Fernando (IV)", por CIRUElos, A y GaRCla SepúlvedA, P., núm. INV. 2.384. - $1.050 \times 500 \mathrm{~mm}$. Enmarcado. En la parte inferior firmado: "Joseph de Churriguera/fbat en Madrid año 1719". En cartela: "Churriguera".

El retablo sigue expuesto en la Sala de Dibujos del Museo. 
$M^{a}{ }^{a}$ TERESA JIMÉNEZ PRIEGO

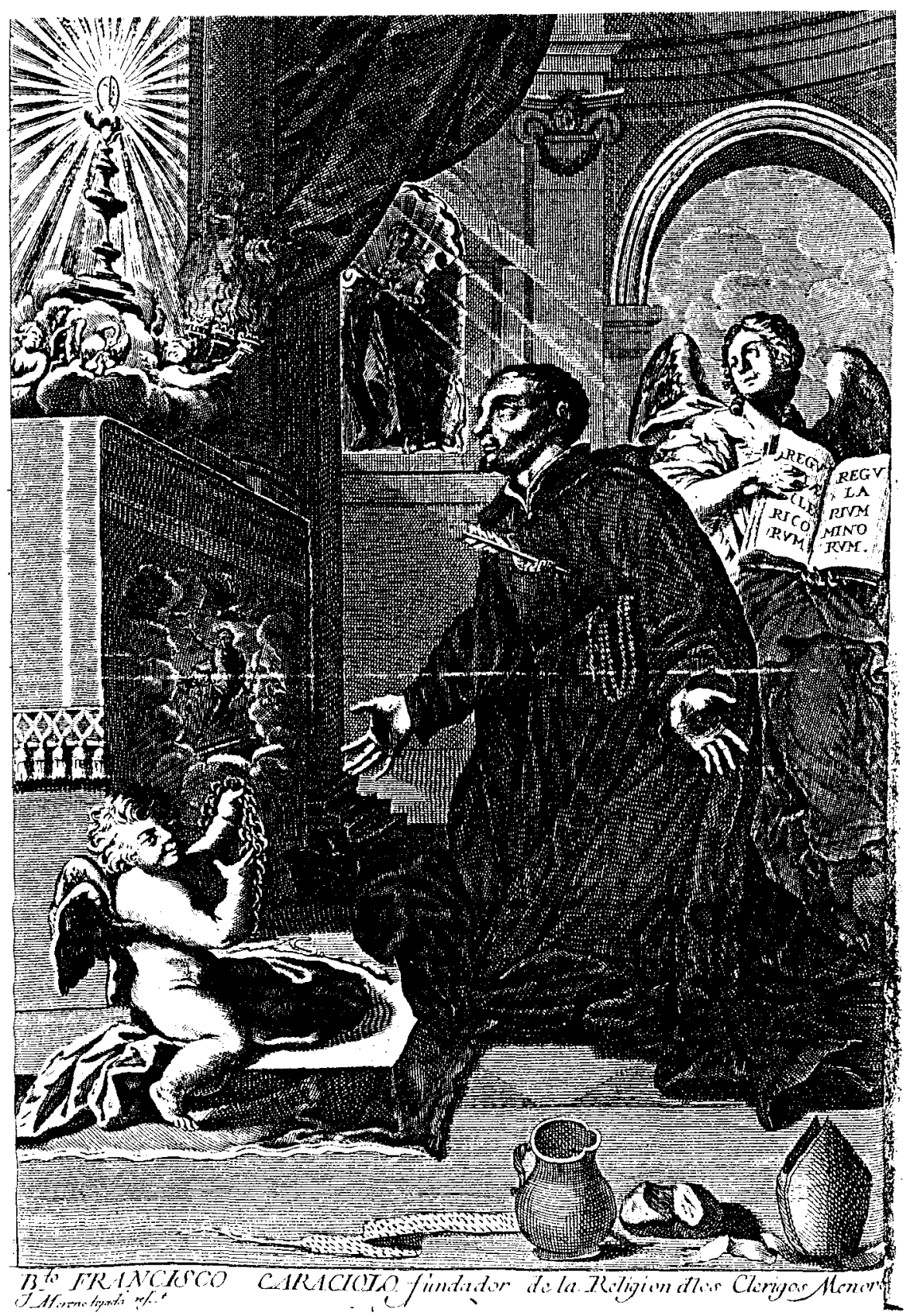

Fig. 6 Grabado de Juan Moreno Tejada, h. 1769. Beato Francisco Caracciolo, fundador. 


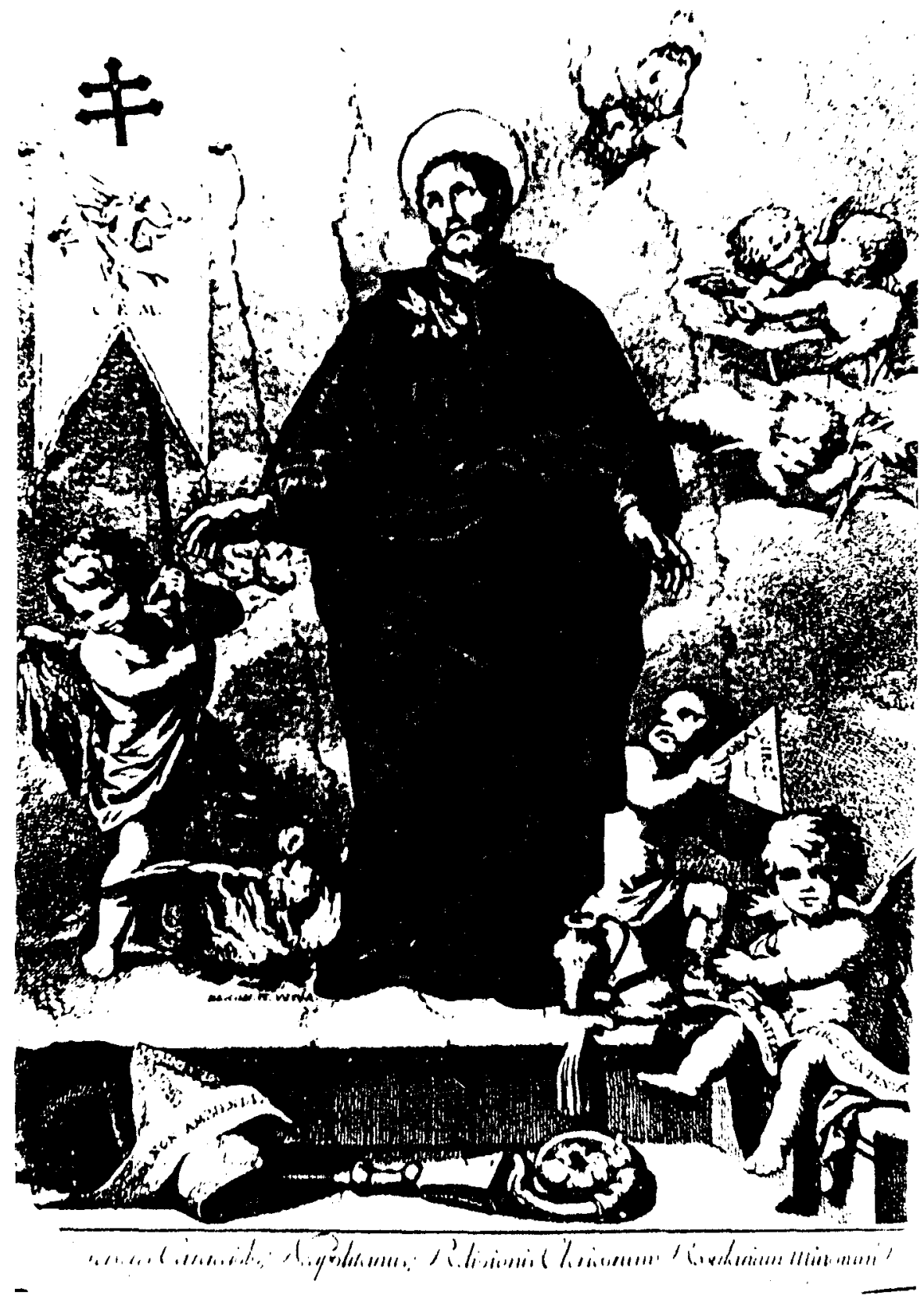

Fig. 7 San Francisco Caracciolo, de Juan Salvador Carmona (siglo xvili). 

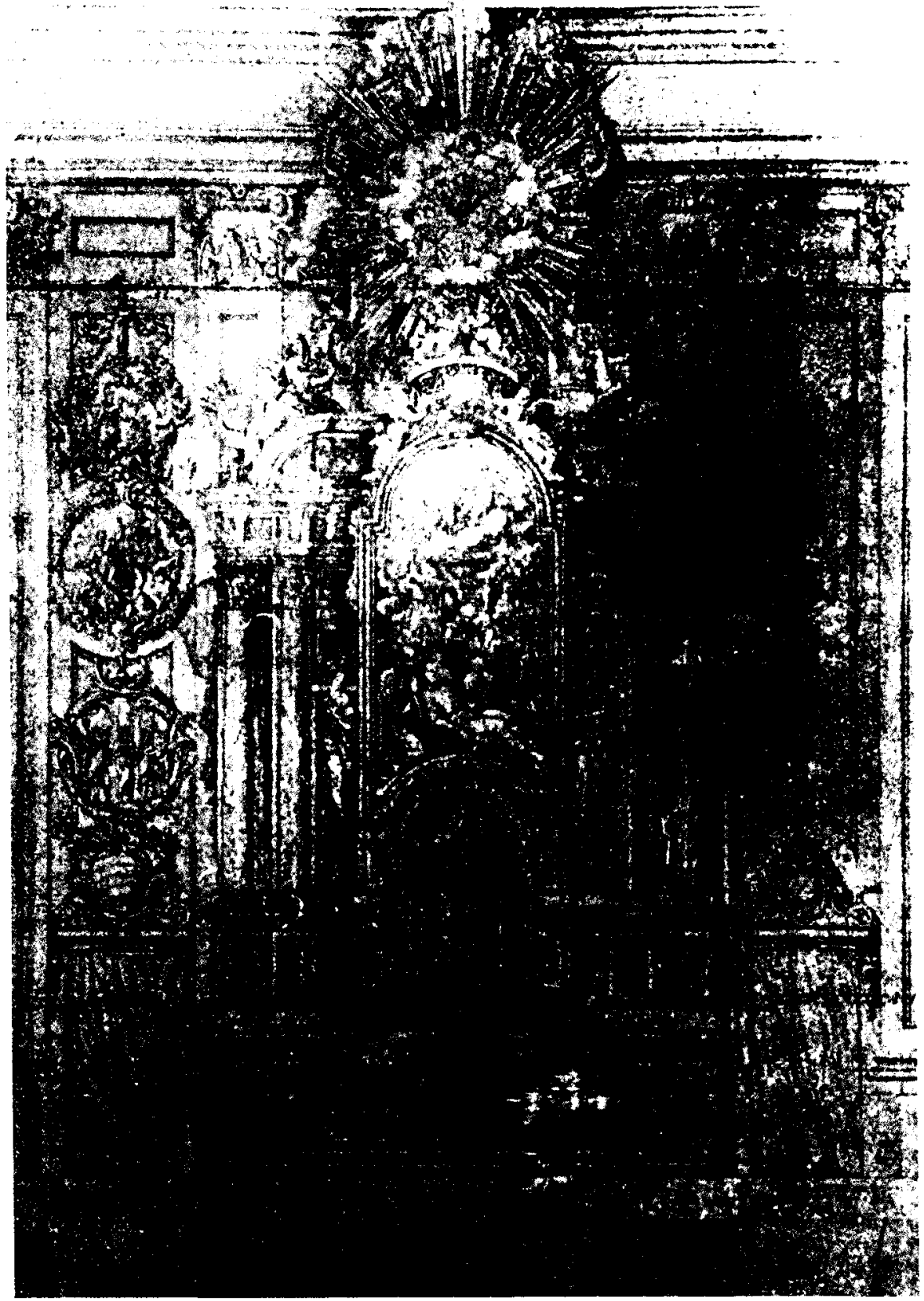

Fig. 8 Dibujo de José de Churriguera, de 1719. "Retablo de San Francisco Caracciolo", en la Academia de San Fernando. 
que, en expresión de Tormo ${ }^{37}$, eran "churriguerescos» y para Ponz ( $V$, $225,27)$ no merecieron mayores alabanzas. Hay que pensar fuera encargado, como el grabado de Salvador Carmona, por los mismos clérigos, mas no podemus identificarlo con las obras reales por no haberse transmitido ningún rasgo o características de ellos, salvo estas referidas, que aludirian a la posible paternidad de Churriguera.

Junto a esta muestras, solamente alguna pintura más.

Al comenzar el estudio de los tres cuadros pintados por Pedro Rodríguez de Miranda observamos que el artista ha tenido varios aciertos.

- Ha concedido a cada personaje su papel y relevancia exacta. A Juan Agustin Adorno le da la primacia. Es el protagonista en las tres escenas. Francisco Caracciolo, también es protagonista, pero lo sitúa como acompañante del verdadero fundador. Creemos que, en esto, $\mathrm{Pe}$ dro Rodriguez es aún más certero que muchos de los historiadores o cronistas de la Orden. Éstos oscurecen la figura de Adorno ante las gestas de Francisco Caracciolo. La posición del artista coincide con la opinión de Luis Moreri ${ }^{38}$, recogida por el P. Quintana ${ }^{39}, y$, por supuesto, con la nuestra propia.

- En segundo lugar ha realizado una correcta selección de los momentos claves, los verdaderos hitos de la historia que narra -la gestación de una Congregación-. Tiene el acierto de no distraernos con milagros espectaculares $u$ otras escenas que podian resultar secundarias y no pasar de "lugares comunes" en este género que podriamos calificar de "pintura de historia sacra".

Cuando intentamos relacionar estas creaciones con otras producidas por deferentes artistas sobre este mismo tema, hallamos poco, apenas esas fuentes gráficas, que hemos citado anteriormente y algo más.

Igual carencia se da en las diferentes publicaciones de iconografia. Réau ${ }^{40}$, Ferguson ${ }^{41}$, Cirlot ${ }^{42}$, Interian de Ayala ${ }^{43}$, etc., lo ignoran. Apenas tres datos con ese carácter en las páginas que le dedican los Padres

${ }^{37}$ Iglesias del antiguo Madrid. 1972. "27. Portacoeli, hoy parroquia de San Martín”, págs. 132-133.

${ }^{38}$ O. C., I, 146.

${ }^{39}$ O. C., "Proemio".

40 Iconographie de l'Art Chrétien. Paris 1955-1958

${ }^{41}$ Signs and symbols in Christian Art. Nueva York 1954.

${ }^{42}$ Diccionario de Símbolos. Barcelona, NCL, 1978.

${ }^{43}$ El pintor cristiano y erudito. Madrid 1782. 
Benedictinos de París en "Vie des Saints" ${ }^{44}$ y Croisset ${ }^{45}$, el cual nos aporta un sencillo grabado que alude a su vida pero sin imágenes ni significados trascendentales. Más completa, aunque escueta, es la descripción iconográfica que hace el Lexikon der Christlichen Ikonographie ${ }^{46}$, y éstas referidas a Francisco Caracciolo, ya que a Juan Agustín Adorno lo sumen en el olvido más total.

Si analizamos estos hechos tenemos que preguntarnos a qué causas responde esta falta de representatividad iconográfica. $Y$ ello nos comprueba la estrecha relación existente entre la ausencia de creaciones pictóricas y la vida misma del Instituto religioso.

Debemos tener presente que la difusión iconográfica no depende tanto de la importancia del tema en sí como del esfuerzo que se realiza en promover la aceptación del culto a ese santo y el deseo de extender su devoción en amplias áreas y en dominios humanos cada vez más extensos. Esto despierta la fuerza generatriz de motivos.

Estas causas no concurrian en este "caso".

La Congregación de Clérigos Regulares Menores nunca fue muy numerosa ni en miembros ni en conventos. Añádase a esto que la peste que asola Nápoles en 1656 ocasiona la muerte de 40 religiosos de aquellas casas, en la estadística de 1934 sólo se menciona a 35 religiosos. Esta fundación era una ligera variante de otras religiones más conocidas -dato que ya les ofreció dificultades para su aprobación-.

Los fundadores murieron muy prontamente y no pudieron dar al Instituto la cohesión que requeria. Agustín Adorno muere en 1591, a los dos años de su profesión religiosa, y Francisco dieciocho años después, cuando él contaba 45 de edad. Hechos tan prematuros ahogaron resultados más sólidos.

La influencia social que alcanzan no es demasiado amplia ni relevante. Afirmación que puede matizarse en Italia en donde la familia Caracciolo es una de las más destacadas de Nápoles y los Adorno pertenecen a la Casa Ducal de Génova. En España tienen estrecha relación, como hemos comentado, con el ilustre Caballero de Gracia.

Todas estas circunstancias determinan la demora en la Beatificación de Francisco Caracciolo, realizada el 4 de junio de $1769^{47}$, y su canoni-

44 París 1948, pág. 77.

${ }^{45}$ O. c., T. 2, págs. $452-454$.

46 Friburgo. Herder 1974. TIMmERS, “Franz Caracciolo CRM», 4.6; pág. 318.

47 Había muerto el 4 de junio de 1608. 
zación, que tuvo lugar el 24 de mayo de 1807 bajo el pontificado de Pío VII ${ }^{48}$.

Estas premisas nos llevan a la conclusión de la importancia del estudio de los lienzos en cuestión, por su carácter único y excepcional en sentido iconográfico. Hemos de realizarlo con el comentario directo o individual de cada pintura, amén de crear la iconografía del santo para que, a partir de este momento, sea incluido en los Diccionarios de este género.

Las escenas representadas nos transportan a tres escenarios diferentes -Valencia, Roma y Nápoles-, y a tres fecha distintas: 1573, 1588 y 1589 , repectivamente.

Siguiendo un orden cronológico a la primera creación a la que hemos de hacer referencia es a la del lienzo que nos sitúa ante el encuentro de Juan Agustín Adorno con San Luis Beltrán, en 1573, en los claustros del convento de Santo Domingo, en Valencia (fig. 9) ${ }^{49}$.

San Luis Beltrán (1525-1581), de la Orden de Predicadores, tiene una revelación sobre el joven noble genovés, que, a su paso por Valencia, visitaba el convento dominicano. Impelido por una fuerza divina se postra ante el huésped y le profetiza «que le tenía Dios destinado para fundar una Religión que había de hacer gran fruto a los fieles", profecía que queda reflejada, además, en la cartela inscrita en el lienzo.

Los dos personajes principales en la representación están perfectamente caracterizados. El Santo viste el hábito de la Orden, de color blanco, compuesto de túnica, escapulario y esclavina con capucha. Su figura queda doblemente resaltada tanto desde el punto de vista pictórico como desde el simbólico.

Desde el punto de vista pictórico, resplandece y destaca la blancura del vestido de San Luis sobre el negro de las capas con las que otros religiosos dominicos completan su hábito.

Simbólicamente, esta blancura, aumentada por la luz que el artista hace incidir sobre la figura del Santo, expresa, en el simbolismo de Chevalier ${ }^{50}$ su iluminación interior, alude en el de Cirlot $^{51}$ a su pureza de

\footnotetext{
${ }^{48}$ Nótese que San Luis Beltrán, su coetáneo, es canonizado en 1677.

49 Este encuentro no es recogido por RybadeneYra, P., o. c., 387-411, ni por VILARRAsa, o. c., págs. 60-71, fiesta del 10 de octubre. Sí en Vies des Saints, de los RR. PP. Bénédictines de Paris. T. IV. Juin. París 1948, págs. 74-78.

${ }^{50}$ Dictionnaire des symboles. Paris 1969 (1982), pág. 206.

51 O. c., págs. 101-102: En el Apocalipsis, el blanco es el color del vestido de los que "han salido de la gran tribulación, han lavado su ropa y la han blanqueado con la sangre
} 


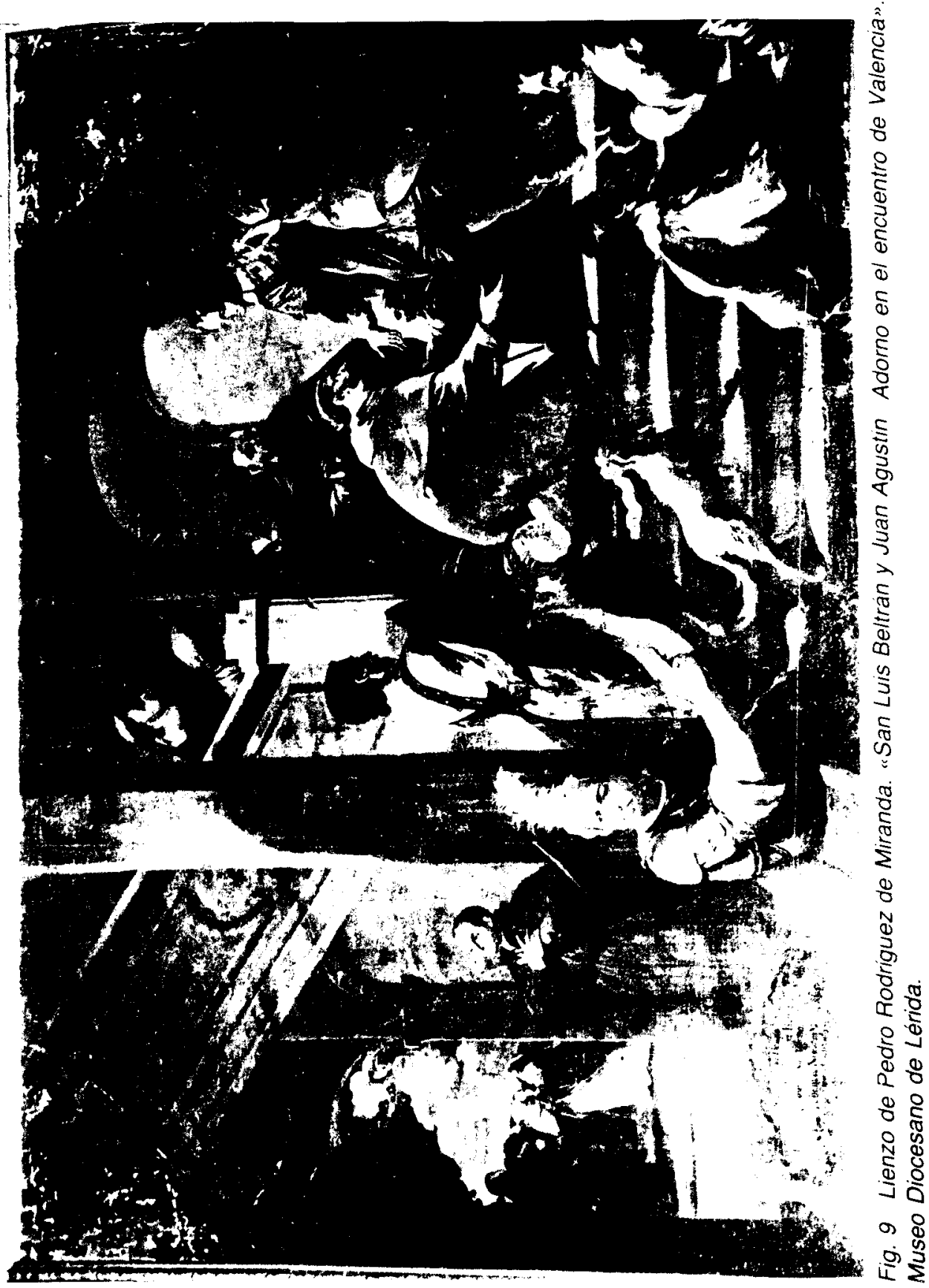


vida, y según Pérez Rioja ${ }^{52}$ habla de su inocencia y virginidad. De forma similar, Alciato lo proclama simple y casto en el emblema de los colores, al decir: "El blanco al simple y casto bien conviene" ${ }^{53}$.

Esta representación de San Luis no corresponde a la primera iconografía dada por el $\mathrm{P}$. Ayala ${ }^{54}$, meditabundo y macilento, ni a la de Cahier ${ }^{55}$ que nos 10 presenta en grupo con los santos que fueron canonizados con él en 1677, bautizando indios (grabado de Ribalta, que custodia Ephialte), con copa o cáliz (la forma más genérica de representarlo, y puede verse en un grabado de Juan B. Palomino, en Ephialte), como predicador (Grabado de Pietro Bombelli, en Ephialte), sino en actitud reverente y profética, que subraya postrándose de rodillas y con el ademán abierto y declamatorio de sus manos ${ }^{56}$.

Frente a él, el joven noble, Juan Agustín Adorno, de pie. Con la misma elegancia y distinción corresponde al oráculo del dominico.

Adorno, contrariamente a la simplicidad del hábito religioso, viste el traje típico de su rango. Porta "sobrevesta», especie de casacón o gabán, usada sobre el resto del vestido. Esta sobrevesta o túnica se sujeta a la cintura, se prolonga hasta casi las rodillas y suele adornarse con los blasones propios del personaje que la lleva. No tiene mangas, lo que le permite lucir las del jubón o camisa interior rematada con amplio cuello o valona y puños de encaje fino de Flandes, que la pragmática de austeridad prohibia a los caballeros en tiempos de Felipe IV. El ajustado pantalón, abrochado por debajo de las rodillas, se une a unas medias ceñidas. Dicha unión está cubierta por unas rodilleras protectoras. Calza un sencillo zapato plano también del siglo XVIII, como el resto del atuendo, con lo que completa el anacronismo, pues la escena tuvo lugar en el siglo $\times V^{5}{ }^{57}$.

del Cordero".-En el mismo sentido abunda MORALES Y MARIN (Diccionario de Iconografía. Madrid, Taurus, 1984, pág. 212) y en "Simbolos", de Diccionarios Rioduero. Madrid, Ed. Católica, 1983, pág. 37.

\$2 Diccionario de símbolos y mitos. Madrid, Tecnos, 1971, pág. 97.

so Emblemas. Madrid, Ed. Nacional, 1975, pág. 243.

${ }^{54}$ O. C., T. 2, L. 8, c. 2, núm. 4, págs. 430-433.

${ }_{55}$ Caracteristiques des Saints dans l'Art populaire. París 1867, 2 vols. Diferentes págs.

${ }^{56}$ La iconografia de este lienzo es diferente a la descrita por ReAu (o. C., pág. 823), Male, Emile, (L'Art religieux après le Concile de Trente. Paris, Colin, 1972, págs. 101-103 y 474-475) o las representaciones de Zurbarán (Museo de Sevilla y Monasterio de Guadalupe, Cáceres), Jacinto Espinosa (Museo de Valencia) o el Baciccia en un cuadro de la Iglesia dominicana de Santa María sopra Minerva, en Roma (Roma e dintorni. Milano 1965. pág. 192).

${ }^{57}$ LAPOULIDE, J., Diccionario gráfico de Arte y Oficios Artísticos. Barcelona 1987 (1932). 4 vols.- Harald Hansen, Henny, Historia gráfica de la moda. Barcelona, Ed. Juventud, 1959.-KLEPPER, El traje a través de los tiempos. Barcelona, G. Gili, 1971. 
La apostura de Juan Agustín en este retrato es elegantemente majestuosa, subrayándola la distinción con que porta el amplio manto. Parece un caballero particular, sin más detalles de riqueza que el cuello y puños de encaje de Flandes. Se presenta con una distinción de cuerpo y ánimo noble. El aspecto de elegante sencillez, sin afectación, está a la altura de esta peculiar circunstancia.

Cada uno de estos personajes lleva su séquito o acompañamiento a tono con su condición social. Tres frailes, en el caso de San Luis, que observan atentos el encuentro. Otros tres caballeros nobles, a juzgar por su atuendo, con el preclaro representante de la Casa Ducal de los Adorno, en Génova.

Próximos al joven aristócrata fundador, aún otras dos figuras, que revelan tener un carácter más secundario a juzgar por la disposición en que los sitúa el artista dentro de la composición. A la derecha del lienzo, una figura masculina, con jubón de mangas con cuchilladas, embozado en su capa, se pierde en la penumbra. A la izquierda, junto a Adorno, postrada de rodillas como san Luis, una figura femenina, quizás la madre de Juan Agustín. Nicoleta Adorno, escucha atónita la profecia. Pensamos que pueda ser su madre por una serie de circunstancias complejas que concurren aquí. El viaje de Génova a España es realizado para huir de las luchas o de la oposición de la nobleza genovesa hacia la familia Adorno. Tiene lugar ei año 1573, en el que Juan Agustín sólo alcanza sus 22 años de edad. Es posible que, dada su juventud y el especial carácter del viaje, fuese acompañado de su madre.

La escena es completada y realzada, a la izquierda por una media figura, de tamaño natural, que parece el presentador del prodigio. Se trata de un caballero, entre aristócrata y guerrero, simétrico a los dos nobles citados que se presentan también como medias figuras de tamaño natural.

Calificamos al "dicente" como guerrero o armado porque se protege con peto y guardabrazos, además de adornar su cabeza, más que protegerla, con cimera o penacho de plumas engastado en un extraño casco.

Con gesto desenfadado nos mira fijamente y con su brazo al desnudo llama nuestra atención y nos introduce en la escena en la que quiere que participemos como espectadores. Su fuerte realismo, sus rudas facciones y su gesto están en consonancia con su corpulencia. Es un tipo que, por sus facciones definidas y su robustez, parece tomado de algunas de las creaciones de Herrera el Viejo. Parece una versión española de algún «dicente» italiano, y aún quizás napolitano. 
Contrasta esta forma poco refinada con la distinción de los otros tres pajes citados —dos simétricos a éste, y un tercero que asciende por las gradas de la escalera, escenario de estos hechos-. Los tres guardan cierta similitud con Juan Agustín en sus ademanes, en su vestuario, -a pesar de ser menos lujoso-, y en el realismo idealizado que los caracteriza.

El escenario del encuentro de los adalides es el rellano o descanso de una escalera imperial, punto de confluencia de las dos direcciones de subida y bajada, y al que se puede ascender por dos lados. Esta situación ha sido buscada, coincide con el cruce de las dos diagonales que dibuja la composición, o como cúspide del triángulo formado por la comitiva que asciende por las gradas de la severa escalinata.

El movimiento ascendente y direccional lo refuerza el artista colocando en la parte central del graderio la figura de un perro que exhibe en su boca la filatelia con la firma del autor y se dirige con decisión hacia el punto culminante.

El perro, en este caso, es todo un símbolo parlante, emblema y alegoria de las virtudes de los personajes a cuyos pies está. Alude a su fidelidad ${ }^{58}$, a su desbordante vitalidad ${ }^{59}$, a su sacerdocio ${ }^{60}$, y, en la simbologia cristiana, como guardián y guia del rebaño ${ }^{61}$. Para Emile Mâle ${ }^{62}$, apoyándose en el criterio de los sacerdotes de Sais, un perro volviendo la cabeza expresa la obediencia.

Finalmente, observemos aún algunos detalles significativos.

El cuadro representa varios episodios sobre el mismo personaje, pero relacionados con distintos puntos o escenarios geográficos y correspondientes a diferentes épocas de su historia vital. Nos narra:

a) La revelación hecha a Catalina Fiesqui y Adorno, (en Génova de donde procede), de que un miembro de su familia había de fundar una religión.

b) L.a concretización de esa revelación en Juan Agustín Adorno, a través de la profecía de San Luis Beltrán (que tuvo lugar en Valencia. España), y

58 Perez Rioja, o. c., pág. 246; Morales, o. c., pág. 268; Revilla, Federico, Diccionario de iconografia. Madrid, Cátedra, 1990, pág. 296.

59 Chevalier, o. c., págs. 18-26.

50-61 Morales y Perez Rioja, OO. CC.

62 "La clef des allégories peintes et sculptées au XVIIlème. et au XVIllième. I. En Italie". Revue des deus Mondes. Paris 1927, pág. 111. 
c) La presentación del protagonista, en Nápoles, ya consagrado sacerdote, en actitud de adoración y aceptación de esa voluntad expresada.

El artista destaca la entrevista que hemos comentado ampliamente concediéndole dos tercios del lienzo y un mayor canon a las figuras, junto a una mayor caracterización de rasgos.

Ha cuidado, también, Pedro Rodriguez de Miranda el verismo de la arquitectura, señera y clasicista, escenario de la representación y perteneciente al Convento de santo Domingo, que fue el más importante de Valencia. Antonio Beltrán ${ }^{63}$ sitúa su construcción definitiva en 1532, la que perduraría esencialmente a pesar de las reformas posteriores. $Y$ al describirnos dicho autor el claustro, parece estar comentando este lienzo. El habla de un "claustro de arcos de medio punto e influencia clasicista", que tiene tres puertas: una de entrada a la iglesia... y las otras dos a la de la capilla de los Reyes y a la aristocrática de la Soledad".

A la izquierda del lienzo, en su tercio restante, como de forma secundaria o para equilibrar la composición, tienen lugar otras dos escenas pintadas a escala menor. Se desarrollan en dos planos perspectivos y se encuentran perfectamente independizados por el pilar que sirve de arranque a dos arcos y de apoyo a la "pendiente" de la escalera.

La escena que se divisa desde el plano espacial más profundo plasma la primera revelación que tuvo lugar sobre la vida del Fundador. En el plano más próximo se nos ofrece la futura realización de esas dos profecias o revelaciones. Juan Agustín Adorno, ataviado con el traje talar, de color negro, propio de los clérigos regulares menores, y consagrado sacerdote, permanece de rodillas, en actitud de adoración, aquella que definirá la principal caracteristica de su orden.

En el cuadro está latente la preocupación porque todo esté definido y estudiado. La improvisación no existe. Las figuras, los elementos, su disposición; el movimiento, la luz, el espacio comportan una intencionalidad y un significado que intentaremos interpretar.

El inspirador del lienzo, tanto como el artista conocia bien la pintura de los siglos XVII y XVIII, estaba introducido o pertenecia a un círculo o mundo simbólico y culto, tan característico del mundo filosófico-científico barroco como del siglo de las luces.

Las miradas, el semblante y los gestos elocuentes, utilizados en su justa moderación, nos comunican los sentimientos que embargan a cada

¿ Guia antistica de Valencia. Barcelona, Aries, 1945, págs. 84-86. 
uno de los personajes y hasta pueden darnos el retrato de su vida interior, que antes hemos comentado.

Existe un equilibrio entre lo profano y lo religioso, entre los objetos familiares de la realidad visible -el perro, la arquitectura, la luz, el movimiento- y su "significación" como emblemas de una realidad superior, «invisible".

La obra está concebida con una unificación del espacio, en que todo forma parte de una totalidad continua e ininterrumpida. El artista ha querido romper la barrera entre la obra de arte y el mundo real, y para conseguirlo representa el tema como si existiera en un espacio coextenso con el del espectador y así el observador se convierte en participe activo del ámbito espacial-psicológico creado por la obra de arte.

Podriamos marcar, sin embargo, una diferencia entre el sistema racional de perspectiva ideado en la escena principal, la de la derecha, y las dos de la izquierda. Mientras que en éstas existe una distancia fija entre el espectador y el tema, creando como una "ventana en el espacio" como la llama Rupert Martín ${ }^{64}$, en la escena del encuentro esta impresión se ha evitado introduciéndonos en el mismo espacio. Aquellas responden a una estética más usada en el renacimiento. Ésta sigue los usos del barroco.

Otro recurso, empleado también por Pedro Rodríguez de Miranda con eficacia, es la representación de sucesivos compartimentos espaciales que nos permiten imaginar una continuidad $\sin$ fin. Las fajas alternas de luz y sombra y los numerosos vanos o espacios menores o secundarios permiten vislumbrar otras partes del edificio y del exterior. El espacio pictórico, en lugar de entenderse como una unidad cerrada y autosuficiente, se trata como un fragmento de una totalidad mayor.

En efecto, el espacio se abre hacia la altura en los ángulos inferior izquierdo y superior derecho. En el primero el mismo cielo desciende a la tierra y, como en el recurso de "trompe l'oeil», unifica el espacio y lo abre hasta el infinito envuelto en nubes y con la presencia del Padre Eterno.

En el ángulo opuesto, de forma más natural, a través de elementos arquitectónicos, se nos insinúan otros espacios abiertos por los que se prolongan y pierden líneas perspectivas y de fuga.

La sugestión del movimiento, al que antes aludimos, puede evocar

${ }^{64}$ Barroco. Madrid, Xarait, 1986, pág. 136. 
la sensación de temporalidad tanto como la de espacialidad. La mirada fugitiva, el gesto momentáneo, hablan de transitoriedad, de mutabilidad, del paso fugaz del tiempo.

Además de una conseguida expresión del tiempo por los movimientos y expresiones de sentimientos y pasiones del alma, el artista simultanea los tres tiempos. Logra un juego temporal entre el pasado (revelación a santa Catalina Fiesqui y Adorno), el presente (encuentro de Adorno y san Luis Beltrán) y futuro (como Fundador en la orden). El pasado y el futuro son evocados a menor escala y en el plano más secundario, significando, quizá, su carácter "no real», mientras concentra toda la atención en el momento presente, central, y lo sitúa junto a una serie de circunstancias que sirven para enaltecer al Fundador -ocupa la cúspide de la composición, lo relaciona con la afamada orden dominicana y en la ciudad de Valencia con uno de sus hijos más preclaros - San Luis Beltrán-.

La luz es otro de los principales medios de expresión utilizado por Rodriguez Miranda. Y esta luz la ha concebido como fenómeno físico y sobrenatural a la vez. La usa como manifestación visible de lo sobrenatural. La revelación divina, en la escena de Catalina Fiesqui, se hace patente por mediación de la luz celestial que penetra iluminando a la santa y al pequeño que lleva en sus brazos, abriendo los ojos a su presencia al que le acompaña.

La arrebatada emoción de la santa, sobrecogida por la súbita aparición del Eterno Padre, se intensifica por el explosivo fulgor que invade su entorno sombrío.

La luz viene de arriba para anunciar a esta mortal la presencia de la divinidad. Este recurso no tiene gran originalidad. Era bastante usado en la representación de temas bíblicos, como "El sueño de Jacob", de Ribera (Museo del Prado).

Este lienzo decoró la sacristía del convento del Espíritu Santo, de clérigos regulares menores, de Madrid. Junto a otros dos cuadros, de los que inmediatamente nos ocupamos. Formaron un espléndido conjunto en gran parte comparable al de la sacristía del monasterio de Guadalupe o al Ciclo Medicis de Rubens, hoy en el Louvre. Como en semejantes ocasiones, estos lienzos no presentan meros episodios de la vida del Fundador, sino lo enaltecen y a la vez sirven de ejemplo a los monjes. La memoria de los Papas y gobernadores fueron tan celebradas como la de los fundadores en programas alegóricos o de carácter histórico, pero siempre grandiosos. 
Aunque los tres cuadros forman un conjunto temático, en cambio los caracteres de ellos son diferentes. El anterior simultanea tres escenas y los tiempos en que ellas sucedieron. Los otros dos desarrollan un solo tema o escena, ocurrida en un solo tiempo, en cada uno de ellos. Una nota común podiamos subrayar: la relación con el espacio celestial, si bien, en cada representación reviste unas características diferentes.

Iconográficamente ia originalidad del que terminamos de comentar es superior al de estos dos que describen escenas bastantes comunes a toda orden religiosa o fundación, como anotaremos.

En contraste con los estudiados recursos compositivos del lienzo comentado, la resolución de éstos, que nos representan la «Aprobación de las reglas de la Orden" y la "Profesión religiosa de los fundadores", es la clásica en este género de obras historiadas, a pesar de ser pintados con distinto planteamiento. La simetría, el estudio simbólico de la luz y la caracterización de los personajes definen al primero. El de la «Profesión", en cambio, está centrado por la "visón" del "cuadro dentro del cuadro" y éste conteniendo o haciendo presente el mundo celestial y dando las claves simbólicas de interpretación de lo pintado.

El lienzo (fig. 10) de la «Aprobación de las reglas por el Papa Sixto $V$. en Roma" es de una belleza sorprendente, tanto por sus calidades pictóricas como por la complejidad escenográfica y de figuras, amén de su relevancia como testimonio histórico e iconográfico de la Congregación.

Recordemos que tras una serie de avatares transcurridos en la vida de Juan Agustín Adorno y Francisco (Ascanio) Caracciolo, decididos a ser fieles a los planes de Dios y crear una orden religiosa, se retiran al eremitorio del Salvador que los Padres Camaldulenses tenian cerca de Nápoles. Alli permanecen cuarenta días componiendo su regla, con la dirección y asesoramiento del P. Pignatelli, su antiguo confesor, y del P. Marinus d'Andria, jesuita. Una vez terminada pasan a Roma para presentarla al Papa y solicitar su aprobación y, con ella, la definitiva fundación de su Orden.

Juan Agustín y Francisco (Ascanio) fueron los elegidos para el viaje a la Santa Sede por todos los clérigos que hasta ese momento se les habían unido en la empresa fundacional, incluido d. Fabricio Caracciolo, familiar de Francisco, y abad, entonces, de Santa María la Mayor de Nápoles, iglesia que sería la primera de la congregación.

A pesar de ser recibidos en Roma con toda pompa a causa de su linajuda procedencia, hallaron ciertas dificultades para conseguir la apro- 


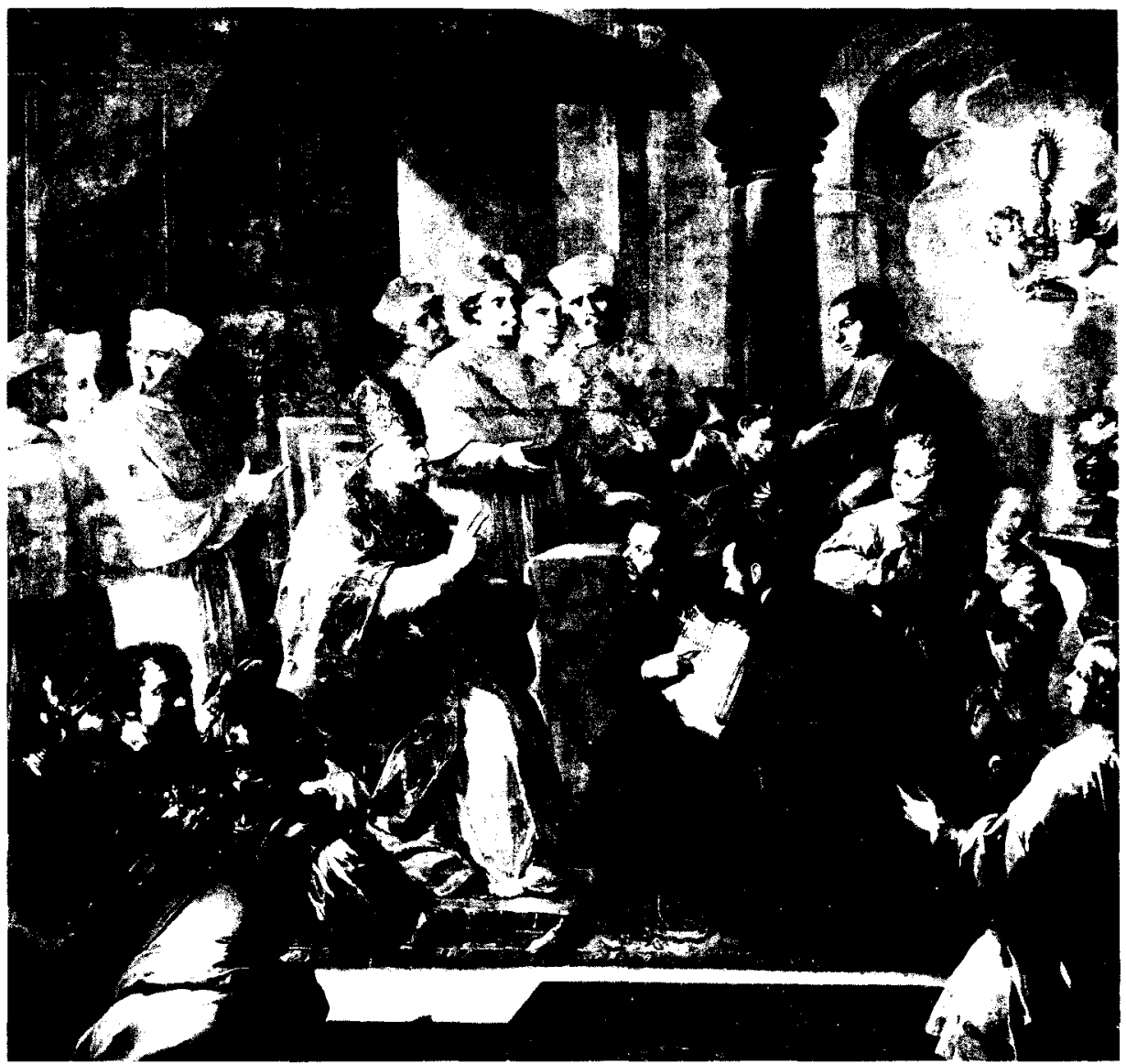

Fig. 10 Lienzo de Pedro Rodriguez de Miranda con la "Aprobación de las Reglas de la Orden por el Papa Sixto V”. Museo del Prado.

bación de su congregación y de las reglas que le darian consistencia. La principal era el gran número de congregaciones de clérigos regulares -teatinos, barnabitas, jesuitas...- que ya existian ${ }^{65}$.

Acompañados de los prelados más influyentes y parte de la nobleza romana expresan al Papa los caracteres más singulares de su futura vida y aquellos que los distinguirian de otras reliogiones - un cuarto voto de

65 Quintana, o. c., pág. 46. 
no aceptar dignidades eclesiásticas, continua oración y penitencia, adoración perpetua al Santísimo-.

El 1 de julio de 1588 reciben la ansiada aprobación, gracias al apoyo del cardenal Montalvo, sobrino de Sixto V. Y adoptan el nombre de Clérigos Regulares Menores, en recuerdo de San Francisco de Asís.

Este momento cumbre es el recogido en el lienzo. El Papa, investido de sus poderes - sentado en su solio, revestido de alba y capa pluvial, y ciñendo la mitra- bendice a los fundadores Juan Agustín Adorno y Ascanio (Francisco) Caracciolo y les concede la Aprobación solicitada. A sus pies los dos religiosos, portan el traje talar y capa, ambos de color negro, con alzacuellos blanco. Llevan el libro de las reglas en sus manos, cuyo texto muestran al Pontífice dirigiendo hacia él sus miradas espectantes.

El acompañamiento es muy nutrido y selecto. A la izquierda de Sixto $V$ están los cuatro cardenales que formaron la Junta que estudió la regla presentada y discutió sus extremos. Estos son: el cardenal de San Severino, el cardenal de Castaña (que después fue el Papa Urbano VII), Lanceloto y el cardenal Justiniano. A su derecha asisten otros tres cardenales, entre los que hemos de suponer al cardenal Montalvo, su poderoso protector por su afinidad con el Papa. Nobles y caballeros, de tamaño natural y pintados de medio cuerpo para indicar la proximidad del espectador a la escena ocupan la parte inferior. Un religioso, sin duda otro protector, los acompaña con extrema atención. Un séquito de niños, nobles o acólitos, completan el número de testigos de hecho tan singular.

Todos estos personajes forman un apretado círculo u óvalo en torno a los Fundadores, que marcan el eje central de la composición, subrayado por la columna clásica, de capitel corintio, de caracteres bastante naturalistas, que se eleva enhiesta en un segundo plano.

La escena tiene lugar en el interior, como nos indica la arquitectura que divisamos al fondo con carácter central. Existe una combinación de columnas geminadas y pilastras de las que parten sendos arcos y nos muestran los amplios espacios de este templo monumental.

Para equilibrar y contrastar los espacios abiertos y cerrados, el artista opone al ángulo firme, sólido y cerrado, como la institución que se alberga en él, en la izquierda, con el abierto de la derecha. No es sino un recurso para mostrar el espacio coextenso, junto con la asistencia y descendimiento de lo divino al plano terrero de los humanos. La idea del continuo espacial, que aquí observamos, es también fundamental en el arte de la escenografia teatral, que trata de coordinar el espacio en perspectiva "del escenario" con el espacio real del espectador. 
La composición, aparentemente narrativa e histórica, no es, en realidad, sino un caso de lo que Rupert Martín ${ }^{66}$ llama de "simbolismo encubierto". Contiene veladas alusiones emblemáticas; por ejemplo, el lugar destacado que concede al pan y al ánfora, junto con las flores, y el rompimiento de gloria con ángeles portando una custodia. Todos estos símbolos hablan del contenido de las reglas que se aprueban y el espíritu que comportan.

La custodia con la Sagrada Forma alude a la principal dedicación de esta orden: la adoración permanente ante el Santísimo. Tanto que se le ha considerado el precedente de la Adoración nocturna ${ }^{67}$. Por esta razón, el ostensorio es uno de los atributos con el que se representa a San Francisco Caracciolo.

El pan y el ánfora simbolizan sus ayunos a pan y agua tres veces por semana. El rosario, cilicios y disciplinas indican su sacrificio y perpetua oración. Los ramos de flores, coronados por la cruz ${ }^{68}$ significan sus virtudes de entrega a los enfermos en hospitales, servicio a los pobres, sus abundantes limosnas, etc., purificado todo por la contemplación y seguimiento de la Cruz.

Miradas, gestos, líneas compositivas, ademanes forman unas fuerzas centrípetas que se dirigen hacia los protagonistas de forma densa y apretada, salvo en la base que se abre reflejando el futuro perspectivo, libre, que ante ellos se abre.

Pictóricamente, el cuadro revela a Pedro Rodríguez de Miranda como un consumado artista. Dominador del color, de la composición, de la perfecta unión y relación de las múltiples figuras que aglutina la escena, amén del acabado estudio y resolución del espacio, con soluciones similares a las comentadas en el lienzo referido al encuentro de Adorno y San Luis Beltrán.

Muy digno de encomio es también la intachable caracterización de rasgos y gestos en cada personaje. La magnificencia y grandiosidad con que nos presenta el anciano Papa. La humildad y sumisión de los dos fundadores. La atenta escucha de los cardenales, en los que, si bien su vestuario es el habitual -vestido rojo con roquete y muceta con alzacueIlo, y la birreta sobre la cabeza - sus rostros nos ofrecen unos verdaderos retratos físicos y psicológicos, tan frecuentes en la pintura española

${ }^{6}$ O. c., pág. 111.

67 Rossi, G., II precursore dell'adorazione perpetua: SFC. Roma 1926 y 1951.

${ }^{6}$ Quintana, o. c., págs. 35 a 39.- Diccionarios de iconografía citados. 
desde fines del siglo XVI y de la época barroca. El mismo cuidado y la misma atención ha prestado a los nobles y guerreros, extremando el derroche de detalles en las figuras de los adolescentes, pertenecientes a la más alta aristocracia, a juzgar por su rico atuendo y abundantes joyas. Sin duda, caracterizan, también, al religioso que los acompaña. Podrían representar, a pesar de su notoria atención, el grupo menos compenetrado con el acto al que asisten. Quizás su ingenua curiosidad se deba a su carácter de meros acompañantes de un religioso de la Sociedad de las Escuelas Cristianas o de alguna otra dedicada a la educación, relacionados con la naciente orden.

Iconográficamente esta representación no tiene antecedentes próximos. Sin embargo, podemos citar una serie de grabados y alguna pintu$\mathrm{ra}$, bastante similares por versar sobre escenas paralelas.

Entre ellos podemos compararlo con el de «Un eclesiástico arrodillado ante el Papa", del pintor Marco Calabrese y el grabador Juliano Traballesi (1727-1812), que se encuentra en la Biblioteca Nacional de Madrid ${ }^{69}$. El parangón entre ambos es notorio y la proximidad, en composición y tiempo, con el lienzo de Rodríguez de Miranda, nos hacen pensar en que éste podia ser su fuente de inspiración. Grandes afinidades observamos, también, en el lienzo de A. Vaccaro "Aprobación papal de la Orden Teatina", custodiado en el Palacio Real de Madrid ${ }^{70}$.

Con menos acompañamiento y de formas más reducidas nos presenta Agustino Ciampelio (Fig. 11) la aprobación de las reglas de la Compañía de Jesús ${ }^{71}$. A pesar de la influencia flamenca, debida al origen de sus autores, el grabado de la reproducción de la primera aprobación de los Barnavitas (fig. 12) (Clérigos regulares de San Pablo), en 1533, obra de Melchor Girardino y Girolamo David, acusa una serie de caracteres comunes con la obra que comentamos ${ }^{72}$. Como mero recuerdo de un acompañamiento señorial y una prestancia notoria, en la que el lienzo de referencia es comparable, recordamos el grabado de la Biblioteca Nacional de París «Decorum indutus est»" ${ }^{73}$.

${ }^{69}$ Sala de Estampas, núm. 5832.

70 Reproducido por Pérez SÁnchez, A. E., La pintura italiana del siglo xvil en España. Madrid 1966, pág. 467, lám. 184. en 1646

${ }^{71}$ Biblioteca Nacional de Paris. Sala de Estampas. N. 80C101157. Grabado en Roma

${ }_{72}$ Reproducido por Pellicia y Rocca en Dizionario degli istituti di perfezione. Roma, Edizioni Pauline, 1969.

${ }^{73}$ Sala de Estampas, núm. 80C101076. 


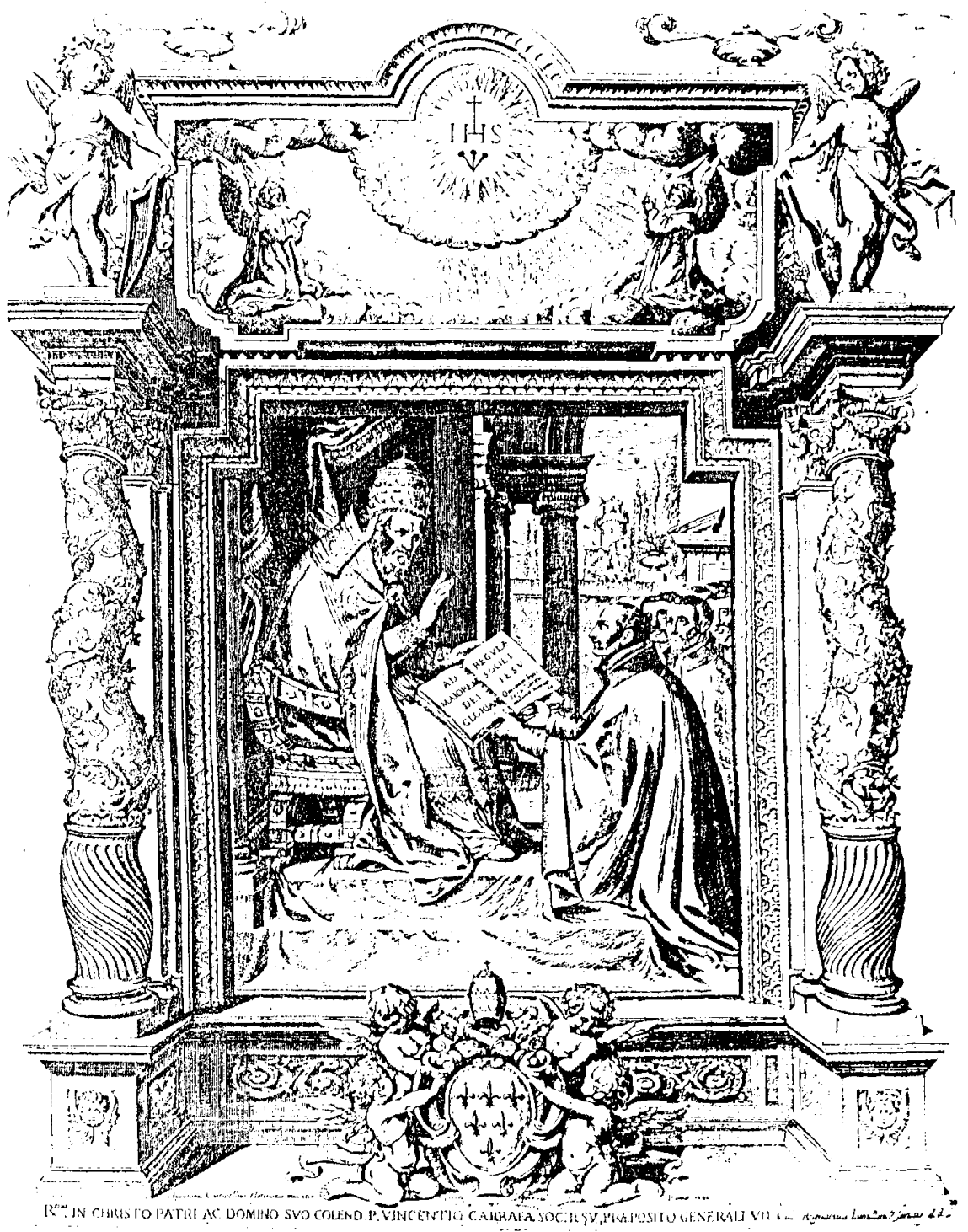

Fig. 11. Grabado de Augustinus Ciampellius, de 1646. 


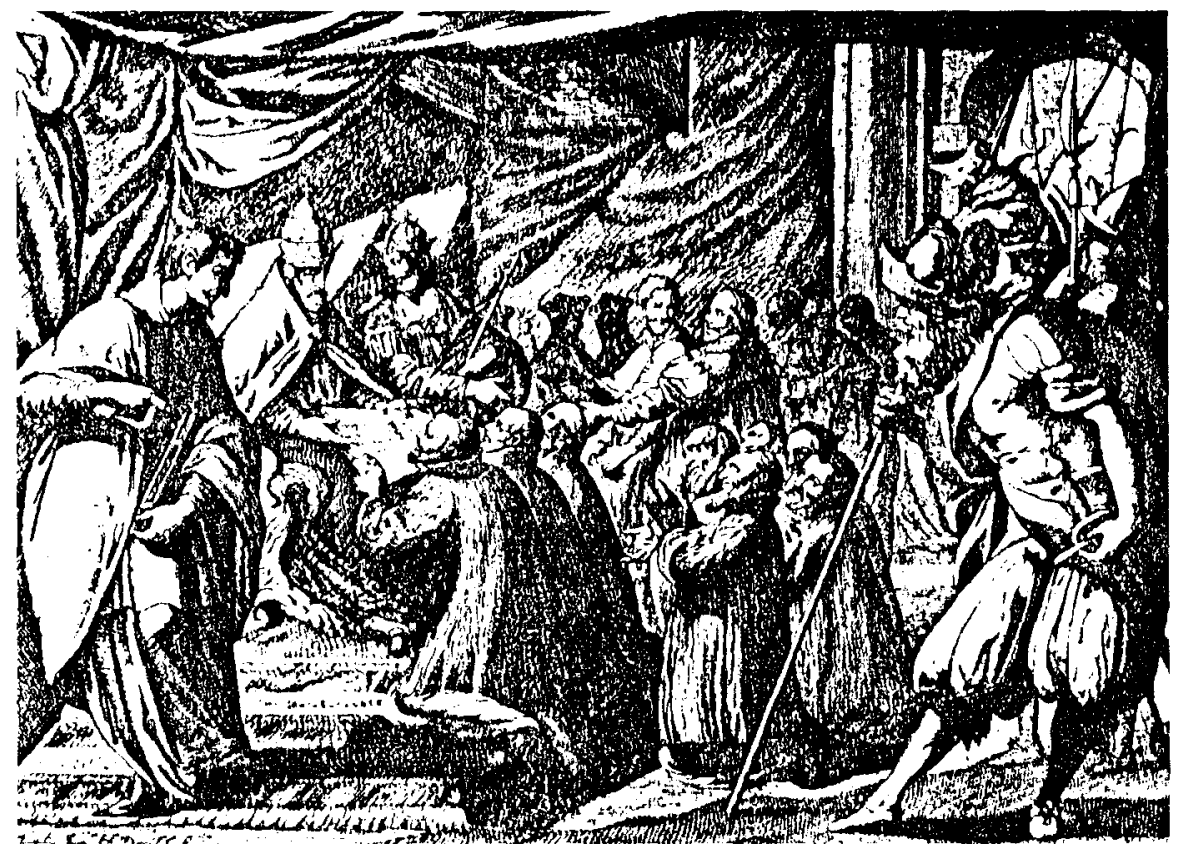

Fig. 12. Escena imaginaria de Melchiore Girardino, grabada por Girolamo David reproduciendo la primera Aprobación de los CRM de San Pablo (Barnabitas) por Clemente VII, el 18-II-1533 en Bolonia.

El último lienzo de esta serie nos inmortaliza la "Profesión religiosa de los fundadores de los Clérigos Reguladores Menores" (fig. 13). Este lienzo se custodia, en la actualidad, en el Prado junto con el de la «Aprobación pontificia de la misma orden».

La escena representada sucede en un interior, dentro de un recinto "Sacro», el Oratorio de Santa Maria Sucurre Miseris, o Nuestra Señora del Socorro, de los Padres Blancos.

El interior "sacro", como afirma Gállego ${ }^{74}$, es género muy apreciado por los pintores españoles, enamorados, como San Ignacio, de lo cotidiano en lo divino. $Y$ además, en este caso, es el escenario obligado para ajustarse a la realidad de los hechos.

Los Padres Blancos fueron los protectores de Ascanio (Francisco) Caracciolo y Juan Agustín Adorno en todo momento. A su lado y en su

74 O.c., pág. 301. 


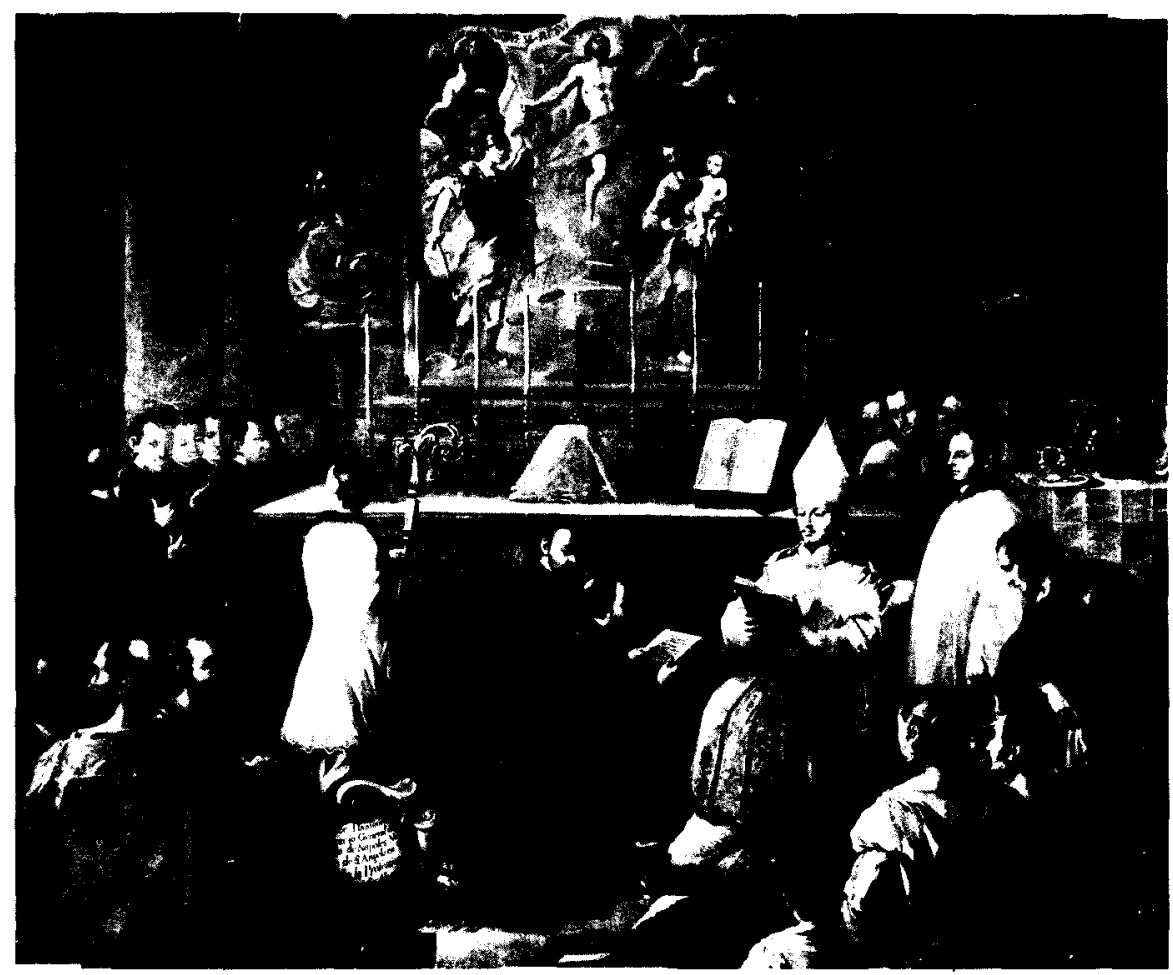

Fig. 13. Lienzo de Pedro Rodriguez de Miranda. "Profesión de los fundadores de los CRM". Museo del Prado.

propia Orden hicieron sus primeros ensayos de vida religiosa. De ella salieron para fundar una nueva, dedicada a un apostolado similar al suyo. A los Padres Blancos vuelven tras obtener la Aprobación pontificia. Con magnanimidad éstos les conceden de su iglesia de Nuestra Señora del Socorro, en Nápoles, y unas construcciones que dependian de ellos.

Alli habitaron durante unos tres años. Mas en 1591 se establecieron definitivamente en Santa Maria la Mayor, de Nápoles, Iglesia y recinto que seria la primera casa de la Congregación de Clérigos Regulares Menores. Recordemos que la obtienen a través de D. Fabrricio (Agustín) Caracciolo, ilustre abad de ella durante muchos años, hasta que se une a la nueva Congregación ${ }^{75}$.

${ }^{75}$ QuINTANA, O.C., pág. 83. 
En la iglesia de Santa Maria del Socorro hacen su Profesión religiosa solemne Ascanio y Juan Agustín, los fundadores, el 9 de abril de 1589, domingo «in Albis».

Esta arquitectura concreta, testigo de esta gesta, es la que se plasma en el lienzo y esta ambientación es la que se "diseña" con los trazos indispensables y esenciales para precisar la escena con todos sus determinantes.

La representación, corresponde, pues, como hemos dicho, a una sola escena que tiene lugar en un solo tiempo. Sin embargo presenta en la realización el mismo gusto que en los lienzos anteriores por crear un espacio coextenso, unir el espacio real con el celeste, o hacer que el exterior invada los dominios del interior. Simultanea, introduce un espacio ideal en un espacio real, más que insertar un espacio exterior en un espacio interno ${ }^{76}$.

El acto convoca junto a los Fundadores a las familias más nobles de Nápoles y al más lucido concurso de religiosos, aquellos a los que habían estado especialmente unidos. Por ausencia del Illmo. Sr. D. Aníbal de Capua, arzobispo de Nápoles, que estaba en Polonia por legado del Papa, les dio la profesión el M. I. Sr. D. Flaminio Torchela, Vicario General de aquella arzobispal diócesis ${ }^{77}$. En dicho acto Ascanio cambió su nombre por el de Francisco, por devoción al santo de Asís.

A toda esta comitiva el artista suma, en momento tan importante, a San Miguel Arcángel, San José con el Niño y Cristo resucitado, los principales patronos de los fundadores y del instituto creado. En ellos evoca la asistencia celeste. El artista los utiliza como "signos" figurativos de una realidad no tangible - la vivencia, fuerte y real, de su protección y compañía-.

Pedro Rodríguez de Miranda circunscribe y constriñe el ámbito celeste al espacio comprendido dentro de un amplio marco. Con esta delimitación y esta forma artificial o poco natural de presentarlo nos manifiesta que en esta pala nos da una serie de "claves" para comprender el contenido y trascendencia del resto de la "historia". O dicho de otro modo, nos hallamos ante el recurso tan usado de cel cuadro dentro del cuadro" como medio de interpretación del tema principal. Gállego en sus

76 Gallego, o.c., pág. 303.

7 Quintana, o.c., pág. 54.-PISelli, Clemente, Compendio della vita del P. Francesco Caracciolo. Napoli 1705, págs. 24-25. 
estudios sobre pintura pone de relieve todas las posibilidades de interpretación de este sistema ${ }^{78}$.

Este cuadro, o este espacio celeste, ocupa la parte superior de la composición y marca su centro de simetria, así como la cúspide del triángulo en que queda toda la escena inscrita.

Mas para entender bien esta extraña composición del fondo, imaginaria o ideal, hemos de hacer ciertas precisiones.

El lienzo, como en composiciones de El Greco, Rafael y otros pintores, principalmente renacentistas, diferencia los planos terrestre y celeste. Pero, mientras que en el «Entierro del Conde de Orgaz», por ejemplo, asistimos a una escena terrestre que tiene su correspondencia celestial aqui, esa relación es más hermética, su "lectura» es más difícil, y solamente las fuentes escritas nos ha podido iluminar esta especie de "jeroglífico".

Es obvio que la unión de estos tres personajes - San Miguel Arcángel, San José y Cristo resucitado- no es usual en ninguna iconografía. En una primera "lectura", sin dejar de resultarnos extraña, podriamos pensar que se nos habla de la muerte (San José es su abogado), el juicio (simbolizado en San Miguel que luce los atributos de la espada y la balanza) y el premio o paraíso futuro (que Cristo mereció con su muerte y resurrección).

Este significado un tanto esotérico, referido al más allá, aludiria a la motivación que estos jovenes profesos podrian tener en su dedicación a enfermos, pobres y encarcelados, asi como a estos destinatarios para alentarlos a sufrir sus desdichas con esperanza.

Sin embargo, no nos parece este "motivo" o alusión el más sugerente para este acto trascendente pero festivo.

En la extensa biografia del P. Eusebio Quintana ${ }^{79}$ sobre Francisco Caracciolo habla ampliamente de la devoción y veneración hacia el Angel de la Guarda, San Miguel Arcángel y San José, sus Patronos. Explica cómo tomaron por Escudo de Armas, como ya anticipamos, la misma Resurrección gloriosa, porque esta religión venía a ser una nueva resurrección en la iglesia, pues por su medio resucitan los fieles, sepultados en las culpas, a la vida de la gracia, y con ese mismo escudo alentaba

${ }^{78}$ Visión y símbolos (1972, págs. 306-324), El cuadro dentro del cuadro (Madrid, Cátedra, 1978) y la Conferencia pronunciada en la Universidad de Harvard (2-VIII-1967).

${ }^{79}$ O. c., págs. $36-37,284$. 
a sus soldados - los clérigos- al seguimiento de la cruz por la aspereza de esta vida con la esperanza de la gloria, buscando en el Instituto sólo LA MAYOR GLORIA DE CRISTO RESUCITADO.

El que este "escudo de armas" sea la insignia o distintivo que aparece siempre junto al fundador nos habla de la importancia que en el Instituto y en la iconografía de la época y posterior tuvo. Lo contemplamos pendiendo entre un amplio cortinón, en forma de medalla o cartela, sobre la Vera effigie di Francesco Caracciolo (Estampa popular contemporánea del Santo, de la Colección Hueter ${ }^{80}$, (fig. 14). Decora el antepecho del altar sobre el que está expuesto el Santísimo y ante el que el santo ora arrodillado (Grabado de Moreno Tejada ${ }^{81}$, fig. 6). Ondea sobre el anagrama de la Orden (CRM) en el estandarte, rematado por una cruz patriarcal, que un ángel eleva junto al santo (Grabado de Juan Antonio Salvador Carmona inspirado sobre un dibujo de Ramón Bayeu ${ }^{82}$, fig. 7). Acompañado de los diversos símbolos alusivos a las normas principales y al espiritu de las reglas aparece este emblema en la parte central del friso superior, en un grabado de L. Spirinx, ya citado, que remata la composición en que se reproducen las efigies de los fundadores y sus "Cofundadores" - como el Papa Sixto V y Agustín (Fabricio antes de ser religioso) Caracciolo, antiguo abad de Santa María la Mayor de Nápoles-, ${ }^{83}$.

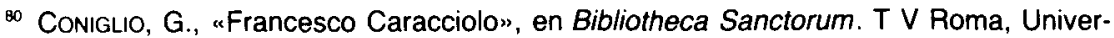
sidad Pontificia lateranense, 1964, págs. 1.197-1.201.

81 Que sirve de portada a la citada biografía del QUINTANA, P. Eusebio.

${ }^{82}$ Este grabado, como dijimos (nota 33), figuró entre las láms. de la Academia de San Fernando. Hoy se encuentran ejemplares en los fondos del Instituto "Ephialte" y entre las “Estampas españolas" del Museo Municipal de Madrid (Catálogo, de Carrete, Juan, y otros, T. I. Madrid 1985, núm. 18).

${ }^{83}$ BNM., Sala de Estampas, núms. 11-12 (núm. 38.805) 228, y en la portada del libro de APONTE, Lorenzo de, sobre los Comentarios del Evangelio de San Mateo (Lugduni 1641). Se contempla en esta portada la síntesis histórica gráfica más completa de la Orden. Recopila en cuatro medallones los retratos de los dos fundadores - Juan Agustín Adorno (genuensis. fundator) y Francisco Caracciolo (neapolitanus. fundator) - y los de los máximos cooperantes al progreso de su religión - Papa Sixto $V$ (approbator) y Augustinus (Fabricio) Caracciolo (neapolitanus. fundator)-. El Papa descansa su mano sobre el pecho mostrando su aprobación y las otras tres efigies portan entre sus manos sendos libros sobre las reglas y otras normas del Instituto.

En la inscripción del arranque de la cornisa se lee en latín: Patriarcas y fundadores de la religión de Clérigos regulares menores.

Precedentes de este grabado, a pesar de su mayor sobriedad, pudieron ser los dos que sirvieron de frontispicio a la Historia de la religión de los Clérigos Regulares -Teatinos- (1609) y de las Constituciones del mismo instituto (1628) o cualquiera de los que se creaban con motivo de las canonizaciones en el siglo XVII, (MALE, E., o. c., pág. 99). 


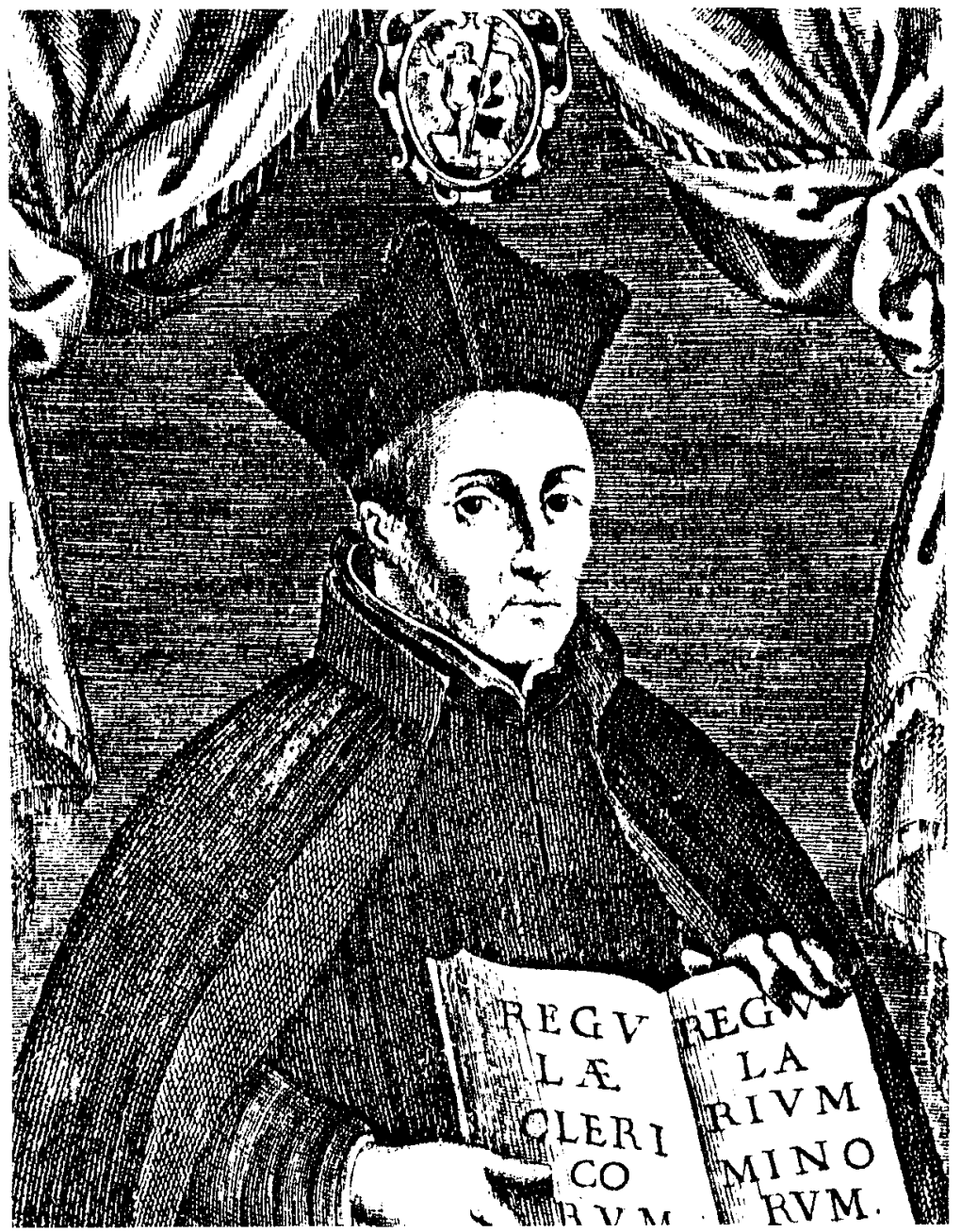

Fig. 14. Vera effige de San Francisco Caracciolo. Siglos xvi-xvil. Estampa popular contemporánea. Coll. Huetter.

Todas estas constataciones nos llevan a cerciorarnos y profundizar en el sentido e importancia de esta iconografía, y a comprender por qué el artista la sitúa como única representación en la parte superior. Ella nos habla elocuentemente del espíritu de las reglas y del sentido último de sus vidas, ella nos brinda gráficamente lo que los fundadores, arrodillados, prometen realizar. 
La posición movida de las figuras, principalmente la del resucitado; el sentido ascensional de éste, elevándose sobre el sepulcro vacío, así como la ilimitada profundidad espacial conseguida por la alternancia de tonos claros y oscuros y los celajes que evidencian el cielo, junto con los ángeles que sostienen la filateria con la divisa principal, contrasta con la escena terrestre, más compleja y más estática.

La escena "real" de carácter terrestre nos queda perfectamente determinada por otro elemento, la cartela colocada en el ángulo inferior izquierdo. Si el cuadro del fondo nos habla del espíritu de la congregación y del contenido de las reglas, la cartela nos identifica los personajes $y$, con ellos, nos da la cronología exacta de los hechos.

La cartela, lo mismo que el estandarte (que hemos observado en el grabado de Juan Antonio Salvador Carmona), el blasón o la tarja, es un elemento figurativo, auténticos objetos-cuadros en si mismos considerados, pero que se colocan dentro de otro cuadro por necesidades de claridad, de identificación o de énfasis ${ }^{84}$.

La cartela, en esta pintura, aparece en la parte inferior del lienzo, como un rico antepecho, en el que descansa su brazo, con aparente distracción o gesto enfatizado, uno de los acompañantes. Su texto nos da a conocer e inmortaliza el acto. Parece el único lenguaje expresivo que se difunde fuera del ámbito circular y espectante que circunda a los protagonistas. Literalmente es como sigue: «Monseñor Flaviano Torcelli (Flaminio Torchelli?) Vicario General de el Arzobispado de Nápoles, Nuncio de Polenta y Obispo de S. Angelo, en virtud de Brebe de el Smo. Pont. Sisto V da la Profession a los VV PP Francesco Carracholo y Agustín Adorno, el día 2 de Abril de el A. D. 1589. Juntando a los tres votos el IIII de no pretender Dignidades".

Su situación es un tanto ambivalente. Por una parte, el hecho de que se nos muestre el mensaje escrito de forma que sólo desde fuera pueda leerse, nos indica que los espectadores no nos encontramos dentro de la acción. Sin embargo, el hecho de que se le de el mismo tratamiento que a las medias figuras, de tamaño natural, del primer plano, indica la intencionalidad de situarnos, o hacernos la ilusión de que to estamos, tan próximos al escenario que formamos parte de él.

La escena histórica, terrestre está presidida por una rotundidad en la arquitectura, un equilibrio en la composición y distribución de masas, así como de una serenidad tan fría que raya en la incomunicación. No existe

${ }_{84}^{8}$ Gallego, o. c., págs. 40-41. 
alusión ninguna, si no es en el espíritu, a to que podriamos llamar "elementos parlantes" comentados. Nada expresivo que relacione ambos estadios. Pertenecen a dos mundos que se complementan pero que mantienen su propio carácter.

Aunque todo gira en torno al hecho cumbre -la profesión de los fundadores-, los asistentes y testigos de él forman grupos independientes con diferente comportamiento. A ambos lados del altar, que preside este interior sacro, sendos grupos de figuras agrupadas entre sí. A la izquierda del lienzo una galería de retratos, todos clérigos, que bien podrían ser seguidores de Caracciolo y Adorno. Si bien no presentan la elegancia de los retratos de El Greco o los mismo de Herrera, en cambio si se presentan revestidos de nobleza y dignidad. Parecen departir algo en común sin que refleje excesiva atención a la trama principal. Este hecho queda subrayado por el gesto del acólito que sostiene el báculo al obispo que preside. Esta misma unión entre sí, con escaso seguimiento del resto, se sorprende en las magistrales medias figuras, próximas a los modelos italianos, con bellas cabezas tan realistas como idealizadas, que ocupan el ángulo inferior junto a la cartela referida.

Carácter muy diferente se observa en los grupos simétricos de la derecha del lienzo. Todas las miradas confluyen atentas en el acto del que son testigos, todos admiran la generosidad e intrepidez de estos jóvenes. Más al fondo, casi en la penumbra, se divisan algunos clérigos revestidos con roquete, como el que porta el acetre y el hisopo con que serán bendecidos los profesos. Otros nobles acompañantes, en posición de tres cuartos o de perfil, reflejan en su expresión la emoción humana que les comporta.

Los grupos descritos se distribuyen en torno al núcleo central en un apretado círculo de fuerzas. El centro lo ocupan los protagonistas. Su aspecto macilento refleja su preparación de austeridad y penitencia. En actitud reverente, ante el Vicario General, señor Torcella, pronuncian sus votos y hacen su Profesión religiosa que es aceptada por el ilustrísimo dignatario. La moderación y sencillez preside este instante, a tono con la trascendencia de esta acción.

Este cuidadoso estudio de caracteres y comportamientos sicológicos nos presenta a Pedro Rodríguez de Miranda como un buen pintor y conocedor de los recursos de este arte. Tiene en cuenta lo que Alberti ${ }^{85}$ consideraba uno de los elementos esenciales de la buena composición,

85 Albert, Sobre la pintura. Valencia, Fernando Torres Ed., 1976, págs. 121 y ss. (Traducción de J. Dols). 
compartido por Lomazzo, Leonardo y otros: el conocimiento exacto de los movimientos del cuerpo en cuanto que expresan las emociones humanas. Lo que en esta composición ha quedado de relieve.

También manifiesta este artista ser un consumado historiador por su forma de sincopar los hechos, principalmente en el último lienzo comentado. En él también se proclama maestro del clasicismo al observar con total corrección las reglas aristotélicas de las tres unidades ${ }^{86}$, subrayadas en nuestro comentario. Se presenta una sola acción, en un solo tiempo, $y$, por tanto, en un solo espacio. He aquí por qué no enlaza directamente los dos escenarios que, figuradamente, aparecen en su pintura.

${ }^{86}$ LEE, Ut pictura poesis. Madrid, Cátedra, 1983, pág. 124. - Las unidades aristotélicas son válidas tanto para la poesia y dramática como para la pintura. 
